OPEN ACCESS

Edited by:

David M. Paterson,

University of St. Andrews,

United Kingdom

Reviewed by:

Conrad Pilditch,

The University of Waikato,

New Zealand

Paulo Cartaxana,

University of Aveiro, Portugal

Rachel Joy Harris,

Loxahatchee River District, Jupiter,

$F L$, United States

*Correspondence:

Trevor J. Tolhurst

t.tolhurst@uea.ac.uk

Specialty section: This article was submitted to Marine Ecosystem Ecology,

a section of the journal Frontiers in Marine Science

Received: 17 October 2019 Accepted: 13 May 2020

Published: 26 June 2020

Citation:

Tolhurst TJ, Chapman MG and

Murphy RJ (2020) The Effect

of Shading and Nutrient Addition on the Microphytobenthos, Macrofauna, and Biogeochemical Properties

of Intertidal Flat Sediments.

Front. Mar. Sci. 7:419.

doi: 10.3389/fmars.2020.00419

\section{The Effect of Shading and Nutrient Addition on the Microphytobenthos, Macrofauna, and Biogeochemical Properties of Intertidal Flat Sediments}

\author{
Trevor J. Tolhurst ${ }^{1,2 *}$, M. G. Chapman ${ }^{1}$ and R. J. Murphy ${ }^{1}$ \\ ${ }^{1}$ Centre for Research on Ecological Impacts of Coastal Cities, Marine Ecology Laboratories A11, School of Life and \\ Environmental Sciences, The University of Sydney, Sydney, NSW, Australia, ${ }^{2}$ Centre for Ocean and Atmospheric Sciences, \\ School of Environmental Sciences, University of East Anglia, Norwich, United Kingdom
}

Proliferation of urban structures and mangrove forests in estuaries are altering the shading of intertidal sediments. Urbanization also tends to increase nutrient loads in estuaries, which can have numerous direct and indirect effects on estuarine flora and fauna. Mangrove canopy shades the sediment and provides nutrients to the ecosystem via leaf litter. Microphytobenthos, macrofauna, sediment erodibility, and various biogeochemical properties of sediments have been shown to differ significantly between unshaded intertidal sediment and nearby sediment under a mangrove canopy. This study tested the effects of experimental manipulation of shading and addition of nutrients on the microphytobenthos, macrofauna, sediment erodibility, and selected biogeochemical properties of exposed intertidal flat next to the seaward edge of a mangrove forest. In the first of two experiments, plots were shaded with roofs to give lightly shaded plots and heavily shaded plots, for comparison with unshaded control plots; nutrients were added in an orthogonal design. Sediment and benthos were sampled after 2 weeks. Nutrients were omitted in the second experiment, with plots sampled after 2 weeks or approximately 3 months. The only effect of nutrients was a small negative effect on chlorophyll $a$ and colloidal carbohydrate. Light shading (clear roofs) generally increased measures of microphytobenthos biomass (e.g., $F_{0}$ and chlorophyll a) and biogeochemical properties associated with microphytobenthos such as colloidal carbohydrate. Heavy shading (black roofs) generally decreased measures of microphytobenthos biomass and microphytobenthos-associated biogeochemical properties. Effects on the fauna were much smaller and inconsistent with previous studies, after 3 months, assemblages were different under heavy shading compared to light shading and unshaded control plots, with differences primarily driven by changes in the oligochaetes. Natural or anthropogenic changes in shading at larger spatial scales are likely therefore to directly and indirectly change microphytobenthos, 
sediment properties, macrofauna and hence ecosystem functions; but any flow-on effects to the fauna are difficult to predict without further experiments to understand the indirect and direct responses of fauna to changing microphytobenthos and properties of intertidal sediment.

Keywords: microphytobenthos, shade, macrofauna, biogeochemical, mangrove forest, intertidal flat, urbanization, ecosystem function

\section{INTRODUCTION}

Many important changes occur in estuaries subjected to increased urban development, including eutrophication, pollution, disturbances associated with boating, increased sedimentation and many others (Chapman et al., 2008; Whitfield and Elliot, 2011). There has been a proliferation of artificial structures into intertidal and shallow subtidal areas (Glasby and Connell, 1999; Chapman and Underwood, 2011; Firth et al., 2016; Bishop et al., 2017), which replace natural habitats; often providing habitat of very different structure and altering physical conditions, such as by shading of nearby sediment. Most research has focused on the organisms inhabiting the structures themselves (e.g., Chapman, 2003), or on fish in adjacent waters (Able et al., 1998; Clynick et al., 2008; Munsch et al., 2014), rather than the surrounding sediment.

As well as directly altering the environment, anthropogenic impacts can cause significant shifts in ecological structure; for example, there has been widespread net loss of mangrove forest area worldwide (Morrisey et al., 2010), but there are locations with large terrigenous sediment supply and accreting intertidal flats, where mangrove forests are spreading into adjacent habitat (Saintilan and Williams, 1999; Morrisey et al., 2010). This has been attributed to anthropogenic impacts such as: climate change, increased inputs of nutrients to estuaries and catchment deforestation causing increased erosion of terrestrial sediment and hence increased estuarine sedimentation (Morrisey et al., 2010).

Urban development can directly and/or indirectly alter water turbidity, which alters the amount of light reaching the underlying sediment bed (i.e., it causes shading) and alters nutrient load, which in turn can alter plankton, phytobenthos such as seagrass (Hauxwell et al., 2003) and microphytobenthos (Stutes et al., 2006). Algal blooms, either on the sedimentsurface or in the overlying water column, have been associated with eutrophication, which can cause major changes to benthic assemblages (Raffaelli, 1999). The relative importance of direct changes to sediment due to shading caused by these blooms, or indirect changes due to anoxia or other processes associated with the algae is not always clear. Shading of habitat can be very important in determining distributions and abundances of organisms, which may be affected either directly by changes in environmental stress, or indirectly via changes to biotic relationships (e.g., Wiens, 1976; Defew et al., 2004; Kon et al., 2011). On rocky shores and seawalls, shading can increase or decrease amounts of algae and change sessile assemblages (Williams, 1994; Blockley, 2007) or cause mobile animals to aggregate (Takada, 1999). Van Colen et al. (2015) demonstrated that in non-shaded controls and bare sediment treatments, microphytobenthos biomass (chlorophyll a) was positively related to the density of Macomona liliana, while no significant linear relationship was found between both variables in shaded sediments; shading-induced changes in bioturbation interference also determined meiofauna densities. Thrush et al. (2014) demonstrated that shade on sandflats altered the interaction network between sediment biogeochemical fluxes, productivity, and macrofauna. However, Pratt et al. (2015) showed there were no significant differences in a multivariate metric of ecosystem function nor the constituent ecosystem function variables between shaded and non-shaded plots on a sandflat. Lundkvist et al. (2007) demonstrated that light is an important forcing factor in the biostabilization of cohesive sediments. Sanger et al. (2004) showed reduced density of saltmarsh vegetation under docks in South Carolina, although it is not known whether this was a direct effect of shade on the plants themselves, or an indirect effect via changes to sediment. Saunders and Connell (2001) showed increased numbers of spirorbid polychaetes on mangrove pneumatophores that were shaded by surrounding seagrass. Subsequent experiments, using artificial substrata, indicated that this was a direct effect of shading on recruitment.

Relatively few experiments have looked at effects of shade on microphytobenthos in unvegetated soft sediments, and they have yielded inconsistent results. A series of experiments in Manukau Harbour investigated the effects of experimental manipulation of shade and grazing pressure on unvegetated sandflat sediments (e.g., Thrush et al., 2014; Harris et al., 2015; Van Colen et al., 2015). They demonstrated that reductions in incident sunlight changed the interaction network between sediment biogeochemical fluxes, productivity, and macrofauna, but did not find an increase in erosion threshold with increasing microphytobenthos biomass. Defew et al. (2002) showed a change in the size of mudflat diatoms in low light conditions in the laboratory in response to shading, but there were no changes in species richness and little effect on biomass, carbohydrate production and photophysiology. When both temperature and shading were manipulated, mudflat microphytobenthic assemblages illustrated a variety of responses to the different conditions, including changes in biomass, pigment ratios, species richness and diversity (Defew et al., 2004). Stutes et al. (2006) showed an effect of shading on micro-algae in the field, but only when there was a large amount of natural light. Given microphytobenthos are important drivers of ecosystem functioning, including food web dynamics (Byers and Grabowski, 2014), sediment erodibility (Black et al., 2002; Tolhurst et al., 2009; Grabowski et al., 2011) and biogeochemical properties of sediments 
(e.g., Tolhurst et al., 2008; Murphy and Tolhurst, 2009), changes in microphytobenthic communities caused by changes in shading and/or nutrients could cause numerous knock-on effects on the sediments they inhabit and other organisms.

The canopy of mangrove trees can cast deep shade over the substratum. Previous work has shown that intertidal benthic assemblages differ between muddy substratum that is continuously shaded, periodically shaded and nearby unshaded substratum (Chapman and Tolhurst, 2004, 2007; Tolhurst and Chapman, 2007; Kon et al., 2010, 2011; Tolhurst et al., 2010). Leaf litter is the largest constituent of mangrove organic matter contributing to food chains (Lee, 2008), the decomposition of which releases nutrients to the ecosystem (Kamruzzaman et al., 2019), although this release is slower in temperate climates compared to tropical ones (Gladstone-Gallagher et al., 2014a). The shaded habitat under the canopy of the mangroves typically has greater amounts of leaf litter, which may affect macrofauna. For example, Lee (1999) demonstrated increased colonization of defaunated intertidal sand in buckets by the addition of mangrove detritus, whilst Gladstone-Gallagher et al. (2014b) found small changes in the relative abundances of a few dominant taxa in response to the addition of mangrove detritus to intertidal flats.

Thus, the expansion of mangrove forests and proliferation of man-made structures into more open habitats (e.g., saltmarsh, mudflat, and sandflat), can result in significant changes to environmental conditions, such as the amount of shading and nutrients, with knock-on effects for ecosystem structure and function. Yet, it remains unclear how much the previously found differences in benthos and properties of the sediment in differently shaded microhabitats are caused by variation in shading, and how much by variation in other components such as leaf litter and nutrients.

Although quantified patterns of differences are essential to underpin causal models, observation alone is not sufficient to distinguish among the many potential models that can explain any pattern (Underwood et al., 2000). Manipulative field experiments allow direct tests of different competing models that can explain a set of observations. The effects of shade may be complex in muddy sediments because shade may directly affect benthos and not sediment, affect sediment and not benthos, or affect both, resulting in highly complex interactions.

This study examined the effects of artificially shading unvegetated intertidal soft sediment adjacent to mangrove forests in Sydney Harbour estuary to mimic the effects of shading by mangrove canopy or man-made structures. The previous differences documented between biota and sedimentary features between the substratum under mangrove canopy and adjacent unshaded intertidal flats (Chapman and Tolhurst, 2004; Tolhurst and Chapman, 2007) could be due to the effect of the shade from the canopy, increased nutrients under mangrove trees from the mangrove detritus, a combination of these two factors, or some other unknown factor(s). If differences are due to shade alone, it was predicted that the addition of shading to sun-exposed substratum would alter the sediment and the benthos to resemble that generally found under canopy. Specifically, it was predicted that amphipods and insect larvae would increase in number and oligochaetes and polychaetes would decrease in shaded habitats.
It was similarly predicted that microphytobenthos would increase under the shaded roofs, which would lead to increased amounts of photosynthetic pigments and colloidal carbohydrate with concomitant increases in the erosion threshold, proportion of fine-grained sediment, and a decrease in erosion rate. Alternatively, if the original differences identified were due to increased nutrients in the sediments under the trees from the greater amounts of filamentous algae and leaf litter, it was predicted that shading would have no effect, but the addition of nutrients to the sediment would lead to the differences in biota and abiotic variables described above. If both shading and increased nutrient levels under canopy caused the original patterns, an interaction between increased shading and added nutrients would be necessary to lead to the original patterns identified.

\section{MATERIALS AND METHODS}

\section{Study Sites}

Two sites in Sydney Harbour estuary, Tambourine Bay and Gore Creek were chosen, the former being one of the locations where the original observations were made (Chapman and Tolhurst, 2007; Tolhurst and Chapman, 2007). They are in very sheltered embayments of Sydney Harbour estuary, with little wave-action except during storms, nor much boat activity. The only public use of the study sites is occasional harvesting for bait (pers. obs.), but the sites were generally undisturbed. They have shallow intertidal flats that are emersed during low tide and during high tide the water is $<2 \mathrm{~m}$ deep, with a narrow strip of mangroves and urban development, including seawalls, at their landward edge. Grain size in the embayments is spatially and temporally variable resulting in mixed intertidal flats, for example at Tambourine Bay mean mud $(<63 \mu \mathrm{m})$ content is $36.6 \%$ (S.E. $6.35, n=15$ ), with a range of $15.5-$ 99.5\% (data converted from mud mass density in Tolhurst and Chapman, 2007). Further physico-chemical data from Sydney Harbour estuary, including from Tambourine Bay can be found in Markich and Jeffree (2019). Data and modeling of nutrients and suspended sediment in the estuary can be found in Birch et al. (2010). The phytobenthos at the study sites include green filamentous algae, diatoms and cyanobacteria. The diatoms and cyanobacteria rarely form visible biofilms like they do in other estuaries around the world, whilst the green filamentous algae often form visible mats on the sediment surface and provide many of the same functions as microphytobenthos (Fagherazzi et al., 2013).

\section{Field Methods}

Two field experiments were completed, with the second modified according to the results obtained from the first. The first was on an intertidal flat at Tambourine Bay, Sydney Harbour (see Tolhurst and Chapman, 2007 for details). On the 22nd February 2005, thirty six $0.25 \mathrm{~m}^{2}$ plots, with $4 \mathrm{~m}$ between adjacent plots, were allocated randomly to nine treatments. Twelve were left undisturbed as an unshaded control and twelve shaded with $0.25 \mathrm{~m}^{2}$ roofs of black Perspex (heavy shading), held 
approximately $10-15 \mathrm{~cm}$ off the surface of the sediment by plastic pipe legs in each corner of the plot. To test for effects of the physical structure of the roofs (other than shading), 12 plots were similarly covered with clear Perspex roofs as a procedural control; however, unquantified observations indicated that a thin layer of sediment settled on the roofs and although it was regularly removed, the sediment under the clear roofs was lightly shaded compared to the unshaded control plots, although not as deeply shaded as the plots with the black roofs. Thus, the three shading treatments were unshaded control, lightly shaded and heavily shaded.

Four replicate plots of each treatment were not further manipulated and four of each were supplied with nutrients. A flexible plastic tube, $1.5 \mathrm{~cm}$ in diameter and with small holes $15 \mathrm{~cm}$ apart along its length, was formed into a ring and filled with Osmocote (Scotts Osmocote Plus, Roses Superfeeder, 15\% $\mathrm{N}, 5.2 \% \mathrm{P}, 10 \% \mathrm{~K})$. Laboratory tests showed that this supplied nutrients continually throughout a 4 -week period and, although amounts of nutrients decreased with time, their concentrations were always more than twice the background level. These rings were carefully buried in the sediment surrounding each plot to a depth of $2 \mathrm{~cm}$. Thus, plots were surrounded by a supply of nutrients, with no disturbance to the plot itself. A procedural control, a similar ring without Osmocote, was applied to the remaining 12 plots ( 4 of each of the shading treatments).

Two weeks later, data from this experiment were collected over 2 days because it was not possible to collect all the samples on the same day. Days were nested within sites to avoid confounding spatial and temporal patterns (Tolhurst and Chapman, 2005), although previous work has shown no significant differences in benthos nor sediment over 2 days (Tolhurst and Chapman, 2007). Accurate quantification and analysis of all pigments present requires destructive sampling and HPLC analysis, which is laborious and expensive (Jeffrey et al., 1999). Remote sensing techniques have advantages over destructive sampling (Murphy et al., 2008), spectroradiometry can reliably estimate the relative amount of absorption by a range of pigments, or groups of pigments (Murphy et al., 2005a). In each plot, the reflectance spectra $(350-1,050 \mathrm{~nm}$, in $1 \mathrm{~nm}$ intervals) were taken in 2 replicate randomly chosen areas under ambient light using an Analytical Spectral Devices (ASD) FieldSpec Pro spectroradiometer (ASD, Boulder, CO, United States details in Murphy et al., 2005a,b). Spectra were taken using an $8^{\circ}$ fore-optic, from a height of $35 \mathrm{~cm}$, thus measuring reflectance from an area of mud the same size as the subsequent contact core sediment samples ( $5 \mathrm{~cm}$ diameter). Each spectral measurement was an average of 30 individual spectra. Immediately prior to the collection of each spectrum, a calibration spectrum was taken from a $~ 99 \%$ reflective panel of spectralon. Two and four replicate spectra were taken from each plot for experiments 1 and 2, respectively. The same replicate $5 \mathrm{~cm}$ diameter areas were then dark-adapted for $15 \mathrm{~min}$ with foil chambers and the microphytobenthic biomass $\left(F_{\mathrm{o}}\right)$ and 'health' $\left(F_{\mathrm{v}} / F_{\mathrm{m}}\right)$ measured using a Heinz Walz Diving Pulse Amplitude Modulation (PAM) fluorometer (Honeywill et al., 2002).

Next a $5 \mathrm{~cm}$ diameter, $\sim 2 \mathrm{~mm}$ deep, cryogenic contact core sample was taken from the same spot as the PAM and spectroradiometer measurements. These cores were immediately wrapped in aluminum foil, stored in liquid nitrogen and returned to the laboratory. The thickness of each core was measured to calculate core volume so the biogeochemical data could be expressed as concentrations (mass density), because of potential confounding of data expressed as content (mass fraction; Perkins et al., 2003; Tolhurst et al., 2005). Then, all samples were weighed, lyophilized in the dark (to prevent degradation of pigments) and stored at $-70^{\circ} \mathrm{C}$ in the dark before analysis of biogeochemical sediment properties.

The erosion thresholds and relative erosion rate (suspension index, $S_{i}$ ) of the sediment were measured adjacent to the sampled areas using a Cohesive Strength Meter (CSM), for more details see Tolhurst et al. (1999) and Vardy et al. (2007). Finally, two benthic sediment cores, $8.5 \mathrm{~cm}$ diameter and $5.0 \mathrm{~cm}$ deep, were collected from each plot to sample the surface macrofauna. Just the surface was sampled because the mangrove roots prevented sampling of deeper sediments in the previous work on which this study is based Chapman and Tolhurst (2004). Two syringe cores of sediment, $2 \mathrm{~cm}$ diameter and $2 \mathrm{~cm}$ deep, were collected to measure grain size and organic matter.

The second experiment was set up in two bays, Tambourine Bay and Gore Creek on 21st April, 2005. Twenty-four plots were established in each site and allocated randomly to unshaded control, lightly (clear roofs) and heavily shaded (black roofs) treatments. Fertilizer manipulation was not included because of the lack of a response in the first experiment. Approximately 2 weeks later, on the 5th May, 2005, 12 of the plots $(n=4$ for each treatment) at Gore Creek were sampled as before to test whether the patterns found previously at Tambourine Bay were also found at Gore Creek. The roofs were then re-used to set up two additional plots of each treatment at each site, giving a total of six plots for each treatment. These were sampled approximately 3 months later, over 2 days on the 4 th and 5 th July, 2005, but because a large storm destroyed most of the plots at Gore Creek, only data from Tambourine Bay were available for analysis. On the 4th July, 2005, light intensity readings were taken in three plots of each treatment and under the adjacent mangrove canopy.

\section{Laboratory Methods}

The type and relative abundance of pigments were obtained from the 2nd-derivative reflectance spectra (Murphy and Tolhurst, 2009). Reflectance spectra were calculated by dividing the mud spectrum by the calibration spectrum. To derive absolute reflectance this quotient was then multiplied by the panel calibration factors provided by the manufacturer of the panel. The relative amount of absorption by pigments was estimated using derivative analysis of the reflectance spectra. First, spectra within each plot were averaged. Second-order derivatives were then calculated from the average spectra using the combined differentiation and smoothing method of Savitzky and Golay (1964), with a $20 \mathrm{~nm}$ smoothing window. Fourth-order derivative spectra may be better at separating individual pigments (Bidigare et al., 1989), but were not used here because they were too "noisy" due to the small reflectance of the mud. Secondorder derivative spectra are centered on zero with peaks in 
the spectrum representing absorption maxima of pigments. The relative amounts of pigments in each plot-average spectrum were calculated by automatically identifying the maximum value in the 2 nd derivative above zero and its wavelength position, for each major absorption in the spectrum. The identity of pigments was inferred by comparing the wavelength locations of maximal absorption with the published wavelengths of in vivo absorption maxima (Bidigare et al., 1989; Smith and Alberte, 1994; AguirreGomez et al., 2001). Absorptions were identified at $419 \mathrm{~nm}$ (chlorophyll $a$ ), $434 \mathrm{~nm}$ (probably a mixture of chlorophylls $a$ and c), $471 \mathrm{~nm}$ (chlorophyll $b$ ), $493 \mathrm{~nm}$ and $587 \mathrm{~nm}$ (carotenoids and xanthophylls), $618 \mathrm{~nm}$ (chlorophyll $a$ ), $630 \mathrm{~nm}$ (chlorophyll $c$ ), and $675 \mathrm{~nm}$ (chlorophyll $a$ ).

The benthic cores were sieved over $500 \mu \mathrm{m}$ mesh and the retained fauna preserved in a $10 \%$ solution of formol-seawater before being sorted under a microscope. Taxonomic resolution was mixed from broad groups (e.g., oligochaetes and nematodes), through families (polychaetes) to species/morphospecies (amphipods, gastropods) because: (i) the taxonomy of many of these groups is not well-known or identification keys are not easily available and (ii) identification of these fauna at mixed resolution is suitable to identify spatial and temporal patterns of variation of these fauna within and among habitats (e.g., Chapman, 1998; Chapman and Tolhurst, 2004).

Contact core samples were used to measure a suite of biogeochemical properties: chlorophyll $a$ and $b$, colloidal and total carbohydrate, water concentration, mud, sand and organic matter using standard methods (see Murphy and Tolhurst, 2009; Chapman et al., 2010 for more details). The concentration of water was calculated from the contact core as $\left(\mathrm{Wt}_{\mathrm{wet}}-\mathrm{Wt}_{\mathrm{dry}}\right) /$ core volume in $\mathrm{cm}^{3}$, where: $\mathrm{Wt}_{\mathrm{wet}}=$ wet weight of the sediment; $\mathrm{Wt}_{\mathrm{dry}}=$ dry weight of the sediment. The colloidal carbohydrates (the water-soluble fraction of carbohydrates) and total carbohydrates were measured from a sub-sample of each contact core using the sulphuric acid-phenol Dubois assay (Dubois et al., 1956). Data were calculated as glucose equivalents using a standard curve and expressed as mass density $\left(\mu \mathrm{g} \mathrm{cm}^{-3}\right.$ for colloidal carbohydrate and $\mathrm{mg} \mathrm{cm}^{-3}$ for total carbohydrate). Approximately $0.2 \mathrm{~g}$ of the freeze-dried sample was used for the assay of colloidal carbohydrate and 0.0025-0.005 $\mathrm{g}$ for the assay of total carbohydrate. Chlorophylls $a$ and $b$ were measured spectrophotometrically from a sub-sample of the contact core using a dimethyl formamide (DMF) extraction, following the equations of Porra et al. (1989) and expressed as mass density $\left(\mu \mathrm{g} \mathrm{cm}^{-3}\right)$ :

$$
\begin{aligned}
& \text { Chlorophyll } a=12\left(A_{664}-A_{750}\right)-3.11\left(A_{647}-A_{750}\right) \\
& \text { Chlorophyll } b=20.78\left(A_{647}-A_{750}\right)-4.88\left(A_{664}-A_{750}\right)
\end{aligned}
$$

Where $A$ are the absorptions at the specified wavelengths.

Organic matter was determined from each contact core and each syringe core by ashing the remaining sediment in a furnace at $450^{\circ} \mathrm{C}$, with the sediment weighed pre- and post-ashing and data expressed as mass density $\left(\mathrm{g} \mathrm{cm}^{-3}\right)$. The grain size was then measured by washing the ashed sediment through a mini $63 \mu \mathrm{m}$ sieve, of known weight. The sieve containing the remaining sand sized sediment was then freeze-dried and re-weighed to determine the mass density of sand $\left(>63 \mu \mathrm{m} \mathrm{g} \mathrm{cm}^{-3}\right)$ and mud $\left(<63 \mu \mathrm{m} \mathrm{g} \mathrm{cm}^{-3}\right)$.

\section{Statistical Methods}

Biotic assemblages and the suite of sedimentary variables were analyzed using multivariate analyses of variance (Permanova; Anderson, 2001). The biotic data used matrices of BrayCurtis dissimilarities and untransformed data and the abiotic data used matrices of normalized Euclidean distances. Levels of probability were estimated from 999 permutations of the data using the reduced model (Anderson, 2001). When factors were significant (at $P<0.05$ ), the means were illustrated in nMDS plots (Clarke, 1993) and means compared using $t$-tests within the Permanova statistical package. The biota and abiotic variables that contributed most to the significant differences among relevant means were identified using SIMPER, which provides the contributions of each individual taxon/abiotic variable to the mean dissimilarity between any two variables.

Univariate data (e.g., abundances of individual taxa, the number of taxa, individual sedimentary variables and individual pigment bands) were analyzed using analysis of variance (ANOVA). First, heterogeneity of variances was tested using Cochran's test and, if significant, significant F-ratios were interpreted with caution. Differences among means for factors with significant F-ratios were identified using Student-NewmanKeuls (SNK) tests (Underwood, 1997a). For all analyses, nutrients (plus/minus/procedural control) and shading (black roofs/clear roofs/no roofs) were treated as fixed factors, with plots nested within the nutrient $\mathrm{x}$ shading interaction. Each site and time were analyzed separately. The differences among treatments, when significant, were over and above plot differences.

\section{RESULTS}

\section{Amounts of Shading}

The light readings showed that average light intensities (photosynthetic photon flux density) on the day of measurement were $1,048 \mu \mathrm{mol} \mathrm{m}^{-2} \mathrm{~s}^{-1}(S E=31)$ in the unshaded control plots, $4.6 \mu \mathrm{mol} \mathrm{m}^{-2} \mathrm{~s}^{-1}(S E=0.93)$ under black roofs, $648 \mu \mathrm{mol}$ $\mathrm{m}^{-2} \mathrm{~s}^{-1}(S E=53.4)$ under clear roofs and $64 \mu \mathrm{mol} \mathrm{m} \mathrm{m}^{-2}$ $\mathrm{s}^{-1}(S E=1.1)$ under the mangrove canopy. The black roof produced sediment more heavily shaded than that under the mangrove canopy, whilst the clear roof produced sediment more lightly shaded than that under the mangrove canopy. The clear roofs decreased average light intensities by approximately 38\%, mangrove canopy by approximately $94 \%$ and the black roofs by over $99.5 \%$. Therefore, the term lightly shaded refers to clear roofs, the term heavily shaded refers to black roofs and unshaded control refers to plots with no shading.

\section{Changes After 2 Weeks, Tambourine Bay and Gore Creek: Fauna}

In the first experiment at Tambourine Bay, 45 taxa were identified, including ten families of polychaetes, seven species 


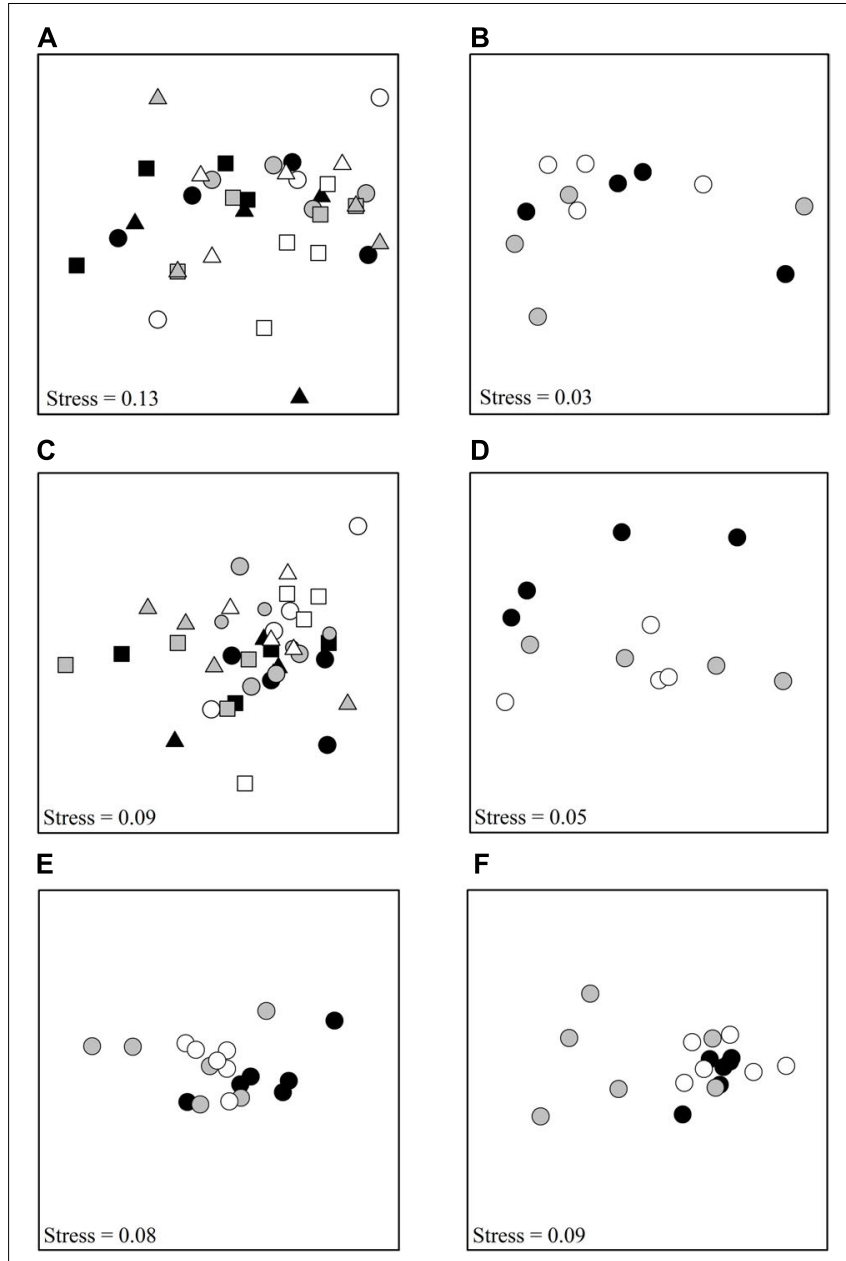

FIGURE 1 | nMDS plots showing differences among treatments, (A) Tambourine Bay macrofauna after 2 weeks, (B) Gore Creek macrofauna after 2 weeks, (C) Tambourine Bay properties of sediment after 2 weeks, (D) Gore Creek properties of sediment after 2 weeks, (E) Tambourine Bay macrofauna after 3 months, (F) Tambourine Bay properties of sediment after 3 months. For panels $(\mathbf{A}, \mathbf{C})$, each point represents 1 plot; black - heavily shaded plots with black roofs, gray - lightly shaded plots with clear roofs, white - unshaded control plots; circles - with nutrients, square - procedural control (buried plastic ring), triangle - no additional nutrients. For the rest of the panels, each point represents 1 plot; black - heavily shaded plots with black roofs, gray - lightly shaded plots with clear roofs, white - unshaded control plots.

of amphipods, eight species of bivalves and groups such as nematodes, insect larvae and oligochaetes. Of the $>4,000$ individuals, approximately $70 \%$ were polychaetes (39\% were spionids). Analysis using PERMANOVA (Anderson, 2001) on untransformed data showed no significant effect of either factor (Shading or Nutrients), nor significant interaction $(P>0.05$ for all terms in the analysis; Figure 1A) and, thus, no effect of either factor on the faunal assemblage as a whole.

The number of taxa, families of polychaetes and abundances of oligochaetes, capitellids, spionids, amphipods, bivalves and nematodes (which together made up $85 \%$ of individuals) were each analyzed using analyses of variance (Table 1A). There were no significant differences among treatments, nor general consistent trends for most data. In some cases, this was due to very small differences among treatments (e.g., the number of taxa in Figure 2). In other cases (e.g., abundances of bivalves, amphipods, and oligochaetes), taxa were extremely variable among some or all treatments (Figure 2). Heavy shading did, however, reduce abundance of spionids and capitellids as was predicted, although this was only significant for capitellids (Table 1A and Figure 2). Adding fertilizer had no significant effect on any of the fauna (Table 1A).

In the second experiment at Gore Creek, there were 27 taxa after 2 weeks, including eight families of polychaetes, one species of amphipods, six species of bivalves and groups, such as nematodes, insect larvae and oligochaetes. Again, there was no significant effect of shading (PERMANOVA; $P>0.80$ ) (Figure 1B). Nor were there any effects of shading on the number of taxa, families of polychaetes, nor abundances of oligochaetes, capitellids, sabellids, spionids, or bivalves (Figure 3, all F-ratios for Treatment had $P>0.05)$.

\section{Changes After 2 Weeks, Tambourine Bay and Gore Creek: Sediment Properties}

The properties of the sediment $\left(F_{\mathrm{o}}, F_{\mathrm{v}} / F_{\mathrm{m}}\right.$, chlorophyll $a$ and $b$, colloidal and total carbohydrate, erosion threshold, erosion rate, mud in contact core and syringe core, sand in contact core and syringe core, organic matter in contact core and syringe core and amount of water) from experiment 1 at Tambourine Bay after 2 weeks were analyzed as normalized Euclidean distances using PERMANOVA. In contrast to the fauna, there was a statistically significant effect of shading in experiment $1(P<0.01)$, with all treatments significantly different from each other (at $P<0.05$ ). Nevertheless, the nMDS (Figure 1C) shows considerable overlap among the different treatments.

The percentage contribution of each variable to Euclidean distance measures among the different levels of shading was calculated for each variable. Sediment in plots without roofs was primarily distinguished from that with light shading by amounts of water ( $10 \%$ of the average distance measure), colloidal carbohydrate $(8 \%)$ and $F_{\mathrm{o}}(8 \%)$. The two types of roof were mainly distinguished by $F_{\mathrm{o}}$ and $F_{\mathrm{v}} / F_{\mathrm{m}}$ (10 and $9 \%$, respectively) and chlorophyll $a$ extracted from the contact cores (8\%).

Analyses of the sedimentary variables for experiment 1 at Tambourine Bay after 2 weeks gave no significant effects of either treatment (shade and fertilizer) on most variables (Tables 1B,C and Figure 4). Light shading caused a significant increase in: $F_{\mathrm{o}}$, concentration of chlorophyll $a$ and water (Table $\mathbf{1 B}$ and Figure 4). There was a strong effect of shading on concentrations of colloidal carbohydrate (Table 1B), with decreased values under both amounts of shading, particularly the heavily shaded ones, which was opposite to what was predicted, but as predicted, there was no significant effect on total carbohydrate. There was a significant decrease in the concentration of sand in the absence of nutrient addition under light shading (Table 1C and Figure 4).

In contrast to the fauna, there was a small, but significant effect of fertilizer on chlorophyll $a$ and colloidal carbohydrate (Table 1B), although Student-Newman-Keuls (SNK) tests could 
TABLE 1 | ANOVA for macrofauna and properties of sediments in plots subjected to Shading (Sh), addition of Nutrients (N) and appropriate control treatments, experiment 1 at Tambourine Bay after 2 weeks; details in text. $20 \mathrm{~mm}$ is data from syringe core, $2 \mathrm{~mm}$ is data from contact core, 2 samples from each of $n=4$ replicate plots.

\begin{tabular}{|c|c|c|c|c|c|c|c|c|c|}
\hline \multicolumn{10}{|l|}{ (A) } \\
\hline Source & df & No. taxa & Fams. Poly. & Oligochaetes & Capitellids & Spionids & Amphipods & Bivalves & Nematodes \\
\hline Sh & 2 & - & - & - & * & - & - & - & - \\
\hline $\mathrm{N}$ & 2 & - & - & - & - & - & - & - & - \\
\hline ShxN & 4 & - & - & - & - & - & - & - & - \\
\hline$P(S h x N)$ & 27 & ** & - & - & - & - & 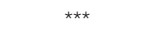 & - & - \\
\hline \multicolumn{10}{|l|}{ (B) } \\
\hline Source & df & $F_{\mathrm{o}}$ & $\boldsymbol{F}_{\mathrm{v}} / \boldsymbol{F}_{\mathrm{m}}$ & Chl. a & Chl. $b$ & Coll. Carb. & Total Carb. & Eros. thres. & Eros. rate \\
\hline Sh & 2 & $\star *$ & - & * & - & $\star *$ & - & - & - \\
\hline $\mathrm{N}$ & 2 & - & - & * & - & * & - & - & - \\
\hline ShxN & 4 & - & - & - & - & - & - & - & - \\
\hline$P($ ShxN) & 27 & * & - & $\star$ & $\star \star$ & 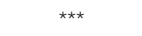 & 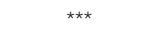 & - & - \\
\hline
\end{tabular}

(C)

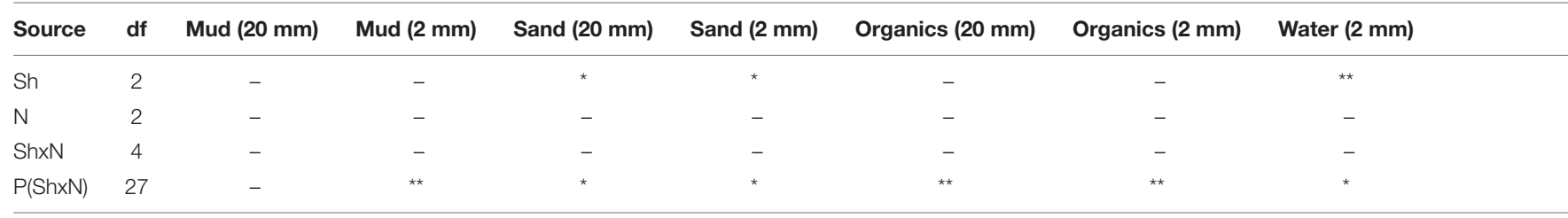

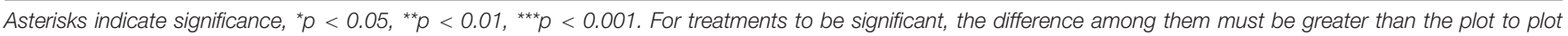
variation.

not distinguish among means. In each case, there were smaller concentrations of chlorophyll $a$ and colloidal carbohydrate in the plots with added fertilizer (Figure 4), which was opposite to what was predicted.

In experiment 1 at Tambourine Bay, after 2 weeks, there was no significant effect of fertilizer on any of the pigment bands (data not shown), but there were significant differences in the amounts of pigments between shading treatments (Figure 5A). The amount of chlorophyll $a$, as measured by the absorption at $675 \mathrm{~nm}$ was significantly different between each of the three shade treatments. Absorptions by pigments at 587, 618, and $630 \mathrm{~nm}$ were significantly greater under light shading, but there was no significant difference in absorption between the unshaded control plots and heavy shading. There was a significant difference between shade treatments at $493 \mathrm{~nm}$, but the SNK test could not differentiate between treatments. At $419 \mathrm{~nm}$ absorption was significantly smaller under light shading than heavy shading and unshaded control plots.

In experiment 2, at Gore Creek after 2 weeks, roofs had no significant effect on the sediment (PERMANOVA; $p>0.20$ ), even though the nMDS plots clearly separated the plots with heavy shading from the other treatments (Figure 1D). Separate analysis of the individual properties using ANOVA revealed significant reductions in $F_{\mathrm{o}}, F_{\mathrm{v}} / F_{\mathrm{m}}$ and colloidal carbohydrate $\left(F_{2,21}=6.72,6.35\right.$, and 6.47, respectively, all $\left.P<0.01\right)$ under the heavy shading (Figure 6), although the decrease in $F_{\mathrm{v}} / F_{\mathrm{m}}$ was small. No other variables showed any significant effect of shading treatments (Figure 6).
In experiment 2, at Gore Creek after 2 weeks, absorptions by pigments at $618 \mathrm{~nm}$ were significantly different among shading treatments (Figure 5B), but the SNK test could not differentiate means. Absorption by pigments at $675 \mathrm{~nm}$ were significantly smaller under heavy shading than both light shading and unshaded control plots, which were not significantly different from each other.

\section{Changes After 3 Months, Tambourine Bay}

Data were only available from Tambourine Bay because the experiment at Gore Creek was lost to a storm. For both the fauna and sediment, nMDS plots and ANOSIM (Clarke, 1993) showed no significant difference between the plots which had been in place for 2 weeks less than the others. Thus, all plots were analyzed together.

\section{Tambourine Bay: Fauna}

After $\sim 3$ months, there were 47 taxa, including nine families of polychaetes, 11 species of amphipods, six species of bivalves, three species of gastropods, five species of isopods and various broad groups, such as nematodes, insect larvae, oligochaetes, copepods, etc. Pairwise comparisons showed that heavily shaded plots had significantly different benthic fauna to the lightly shaded and unshaded control plots, which were similar (PERMANOVA; $p<0.05$; Figure 1E).

Differences were primarily due to abundances of oligochaetes (which contributed $24 \%$ to the total dissimilarity between heavily 

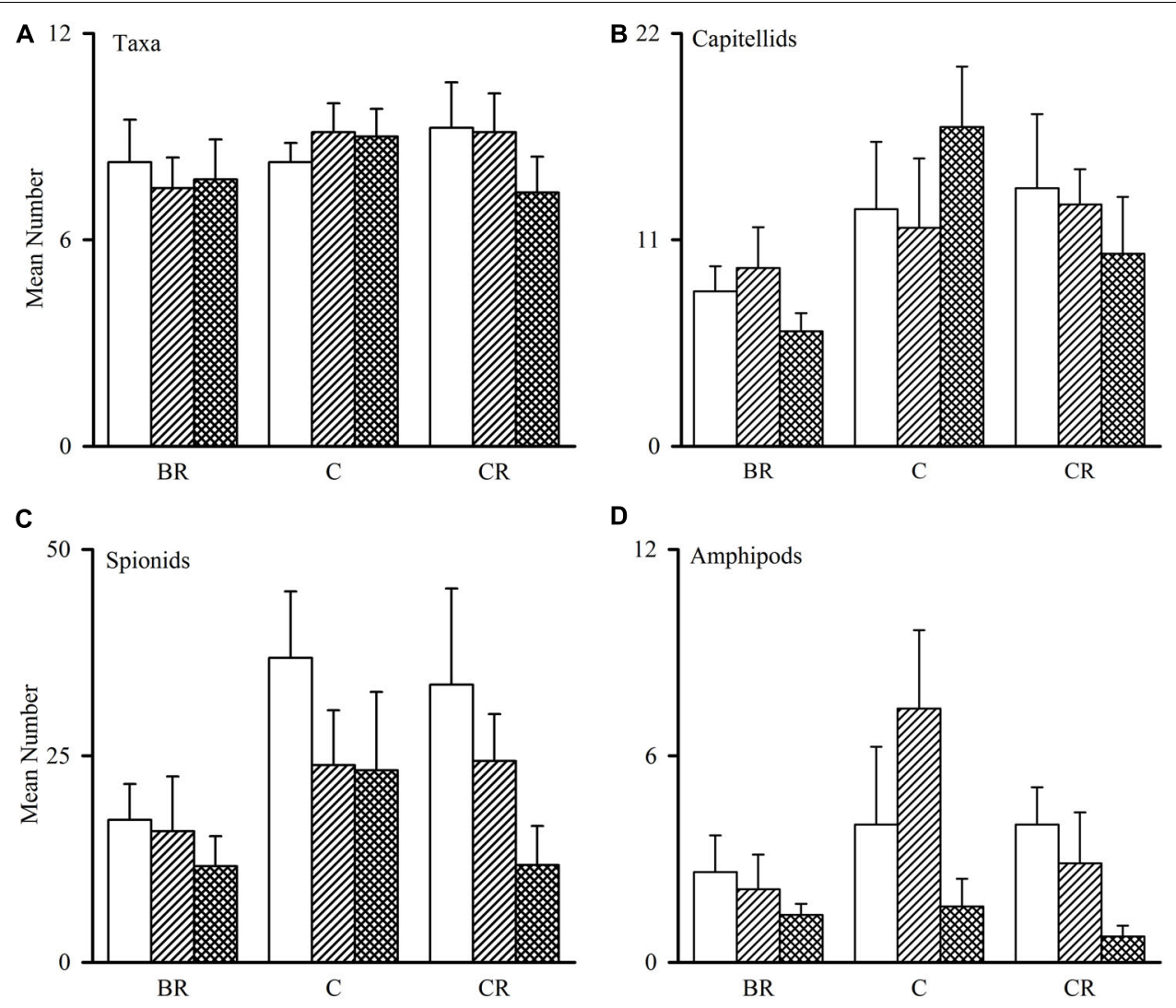

D
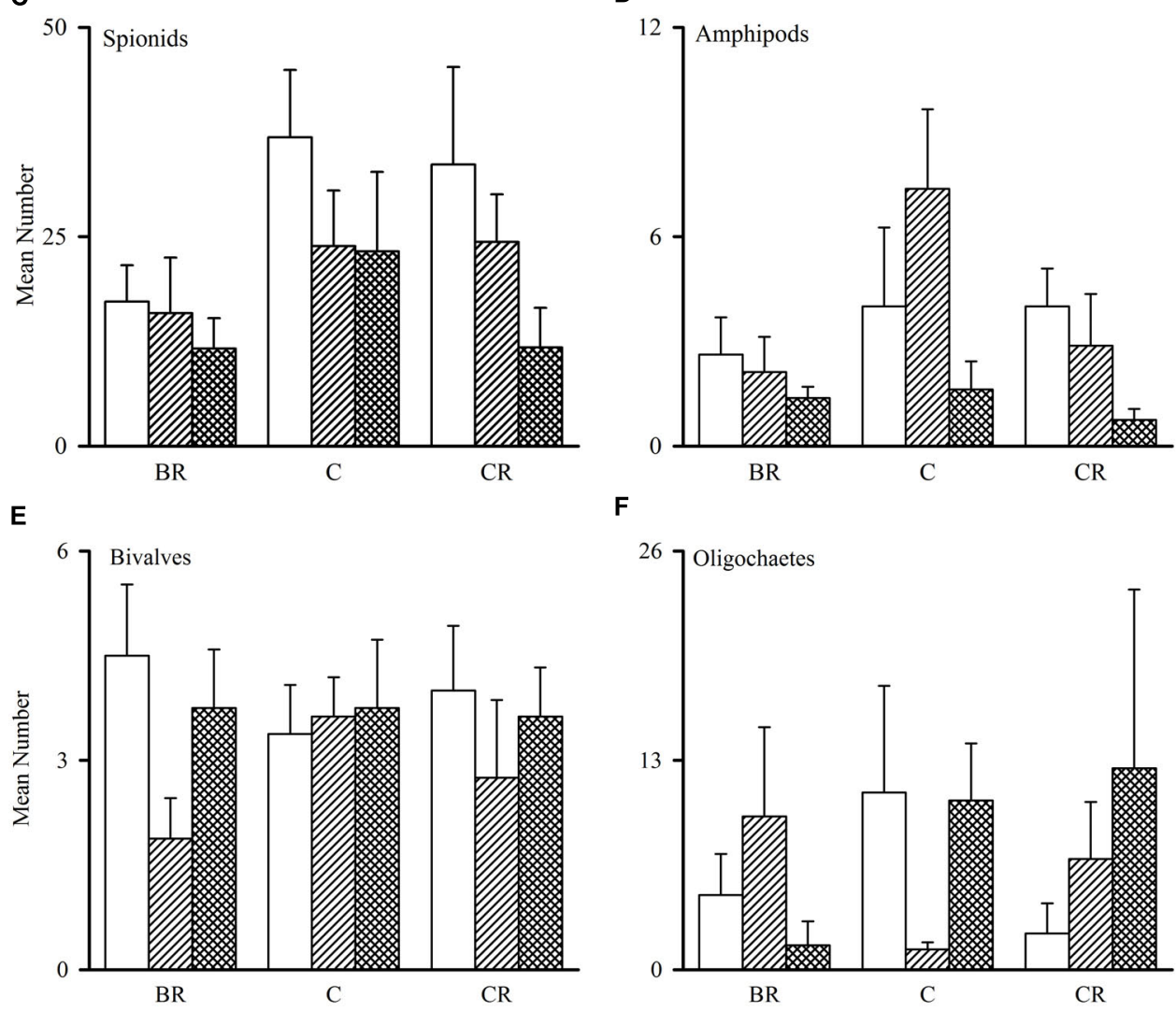

F

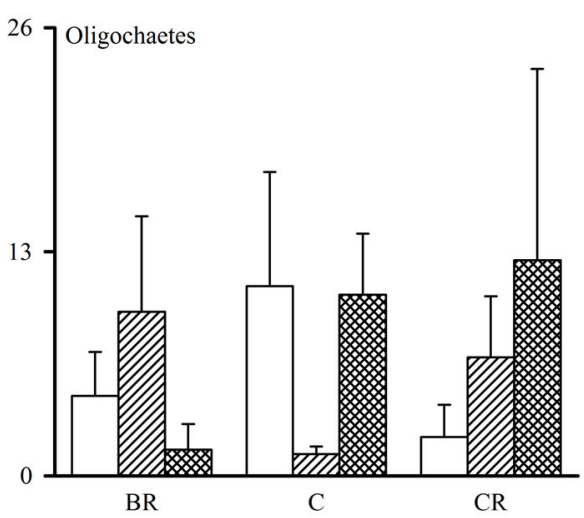

FIGURE 2 | Tambourine Bay macrofauna after 2 weeks, mean (SE.; $n=4$ plots). Panel (A) numbers of all taxa and abundances of (B) capitellids, (C) spionids, (D) amphipods, (E) bivalves, and (F) oligochaetes in heavily shaded plots with black roofs (BR), lightly shaded plots with clear roofs (CR) or unshaded control plots (C), when provided with added nutrients (white bars), no nutrients (linear hatched bars) or the associated procedural control (crosshatched bars).

shaded and lightly shaded plots, $23 \%$ to the dissimilarity between heavy shading plots and unshaded control plots), sabellids (17 and $12 \%$, respectively), spionids (17 and $19 \%$, respectively) and one species of gammarid amphipod $(11 \%$ for the latter comparison only).

The number of taxa, families of polychaetes and abundances of oligochaetes, capitellids, nereidids, sabellids, spionids, amphipods, and nematodes were analyzed using analysis of variance, the other taxa being too sparse for analysis, i.e., data dominated by zeroes and singletons (Table 2). Several of these taxa showed significant variability among replicate plots, but only the number of taxa and abundances of amphipods showed significant differences among treatments. SNK tests could not identify the differences among treatments for the number of taxa, although there were fewer under heavy shading and more under the light shading (Figure 7). Abundances of amphipods were significantly reduced under both sets of roofs, which indicates an experimental artifact. Despite the strong contribution of oligochaetes to the multivariate patterns and large decreases in oligochaete, sabellid, and nereidid polychaete abundance under 


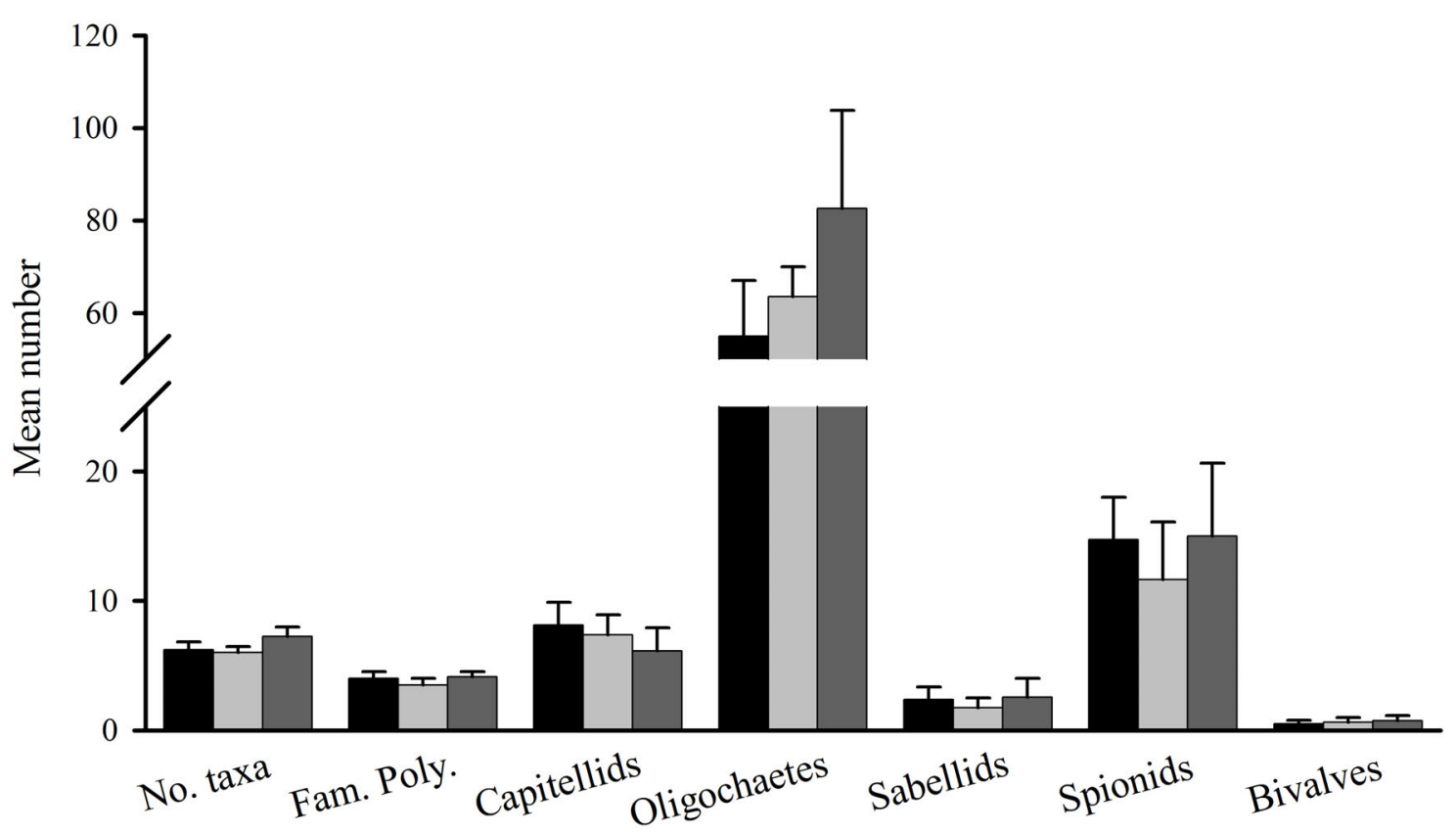

FIGURE 3 | Gore Creek macrofauna after 2 weeks, mean (SE; $n=4$ plots) number of taxa, families of polychaetes and abundances of capitellids, oligochaetes, sabellids, spionids, and bivalves in plots with black roofs (black bars), clear roofs (dark gray bars), or control plots (light gray bars).

heavy shading (Figure 7), there was no significant effect of heavy shading (Table 2).

\section{Tambourine Bay: Properties of Sediment}

After $\sim 3$ months, roofs had no significant effect on the sediment (PERMANOVA, $P>0.25$ ), mostly due to very large and significant differences among plots. It is clear from Figure 1F, that four of the six plots with light shading were very different from the other two plots with light shading, which plotted together with those with heavy shading and the unshaded control plots. These two plots with light shading were not the plots that had been in the field 2 weeks less than the other plots with light shading.

Although differences were not significant, because four of the six plots with light shading were clearly separated from the other plots on the nMDS plot (Figure 1F), SIMPER determined which variables most contributed to differences in sediment between the plots with light shading and the unshaded control plots, or those with heavy shading. The entire range of variables measured contributed similar amounts to the differences, with no single property contributing large amounts to the overall differences in sediments.

In contrast to the fauna, there were significant differences among treatments for many of these properties of sediments; these were $F_{\mathrm{o}}, F_{\mathrm{v}} / F_{\mathrm{m}}$, chlorophyll $a$, water, total and colloidal carbohydrate and sand in both types of core (Tables $2 \mathbf{B}, \mathbf{C}$ and Figure 8). In general, there were more significant differences in the biochemical properties than in the physical properties of the sediment. There were no significant differences in threshold or rate of erosion, despite the significant changes in the amount of microphytobenthos, water and sand in the surface sediment.
Most significant differences in the properties of the sediment were between the plots with light shading and the other treatments (SNK tests). There was significantly more chlorophyll $a, F_{\mathrm{o}}$, total and colloidal carbohydrate and water under the light shading than in the other two treatments (Figure 8). In all analyses, heavily shaded and unshaded control plots did not differ significantly, despite reduced measures of $F_{\mathrm{o}}$, chlorophyll $a$ and colloidal carbohydrate under heavy shading (Figure 8). $F_{\mathrm{v}} / F_{\mathrm{m}}$ showed the opposite pattern to $F_{\mathrm{o}}$, being significantly smaller under the light shading.

Although there were significant effects of treatments on amounts of sand, SNK tests could not distinguish among the means. There appeared to be an artifact associated with roofs influencing the amounts of sand and mud, with increased mud and decreased amounts of sand under both sets of roofs compared to the unshaded control plots. The rate of erosion was greatest under heavy shading and least under light shading (Figure 8). The threshold of erosion did not differ significantly among treatments, but was slightly reduced under heavy shading.

After 3 months at Tambourine Bay, absorption by pigments at $419 \mathrm{~nm}$ was significantly less under light shading than under heavy shading and unshaded control plots, which were not significantly different to each other (Figure 5C). There was no significant difference in absorption among shading treatments at $471 \mathrm{~nm}$. At $675 \mathrm{~nm}$ heavily shaded plots had significantly smaller amounts of absorption than both lightly shaded and unshaded control plots, which were not significantly different to each other. For all other wavelengths, light shading showed significantly greater amounts of absorption than both heavily shaded and unshaded control plots, which were not significantly different to each other (Figure 5C). 

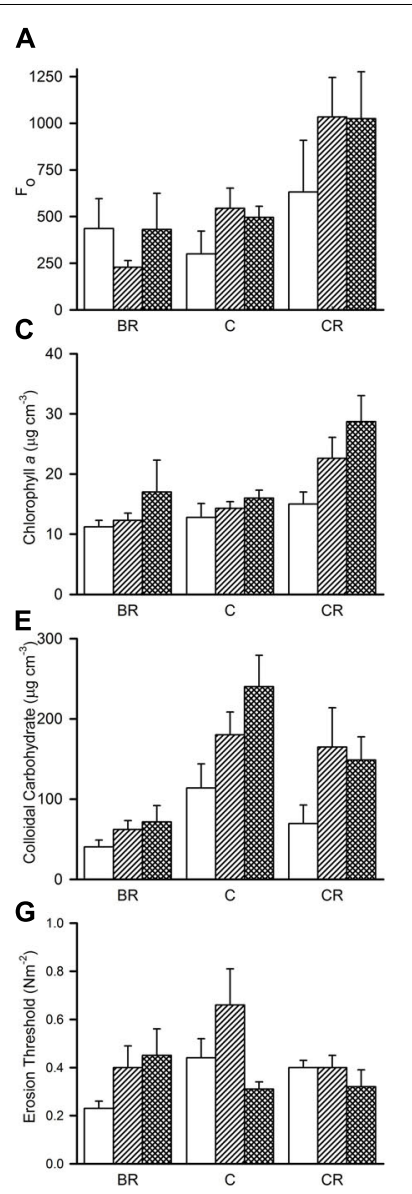
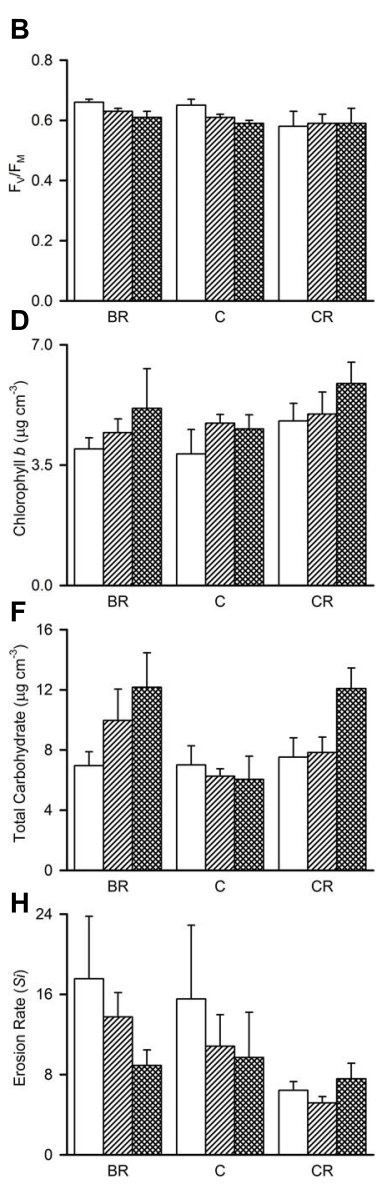

I
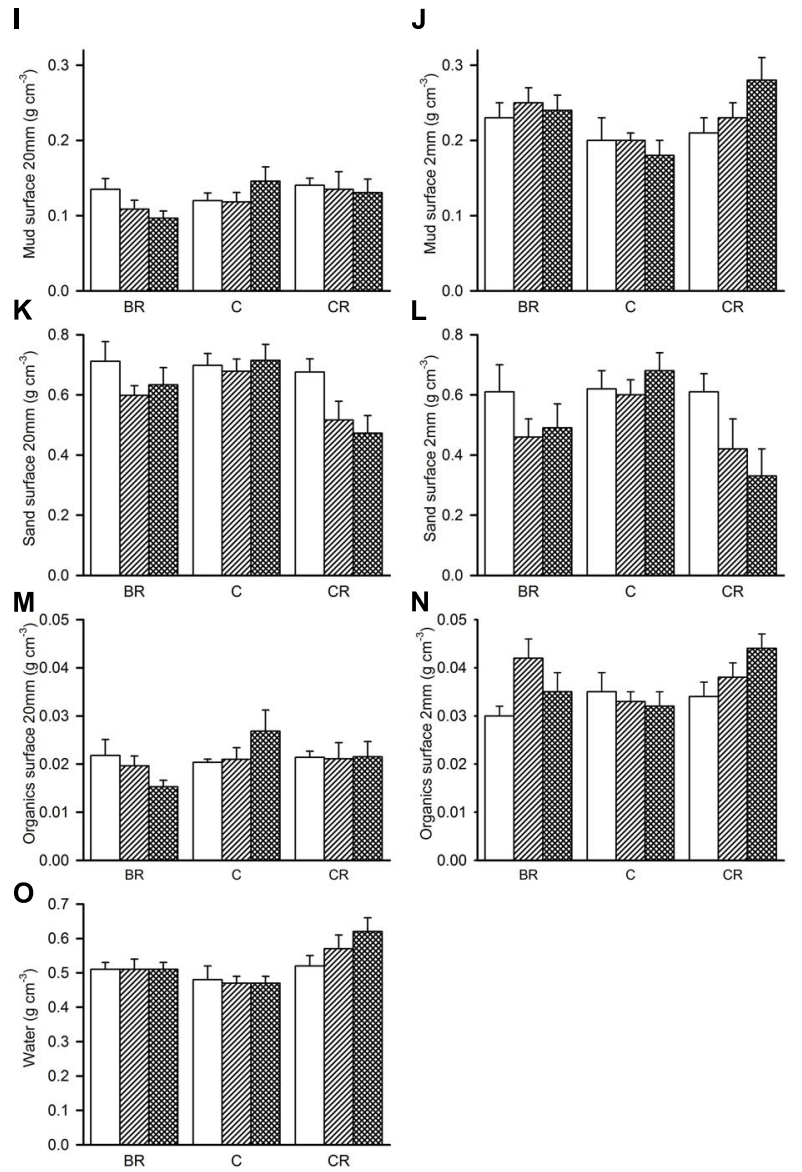

FIGURE 4 | Tambourine Bay properties of sediment after 2 weeks, mean (SE; $n=4$ plots) in plots with black roofs (BR), clear roofs (CR), or unshaded control plots $(\mathrm{C})$, when provided with added nutrients (white bars), no nutrients (linear hatched bars), or the associated procedural control (crosshatched bars). Panel (A) $F_{0}$, (B) $F_{\mathrm{v}} / F_{\mathrm{m}}, \mathbf{( C )}$ chlorophyll a, (D) chlorophyll b, (E) colloidal carbohydrates, (F) total carbohydrates, (G) erosion threshold, (H) erosion rate, (I) mud from 20 mm deep core, (J) mud from $2 \mathrm{~mm}$ deep core, (K) sand from $20 \mathrm{~mm}$ deep core, (L) sand from $2 \mathrm{~mm}$ deep core, (M) organics from $20 \mathrm{~mm}$ deep core, (N) organics from 2 mm core, and $(\mathbf{O})$ water from $2 \mathrm{~mm}$ deep core. $F_{\mathrm{o}}$ and $F_{\mathrm{v}} / F_{\mathrm{m}}$ measured with a PAM (unitless); erodibility measured with a CSM, erosion threshold ( $\mathrm{N}$ m ${ }^{-2}$ ), erosion rate (dimensionless); all other measures are mass density (wt per $\mathrm{cm}^{-3}$ ).

\section{DISCUSSION}

These experiments show that both light shading (produced by the clear roofs) and heavy shading (produced by the black roofs) can, within a few weeks, cause significant changes in microphytobenthos, properties of sediments and some macrofauna. In contrast, there was little to no effect of addition of nutrients. Shading by saltmarsh plants has been found to cause similar changes, altering physical properties, shifting microphytobenthos communities to diatom dominance and altering macrofaunal community composition (Whitcraft and Levin, 2007). This suggests that shading is a fundamental driver of intertidal sediment ecosystem structure and function in these Australian habitats.

\section{Effects of Roofs}

Mangroves in Sydney Harbour are patchy and do not form a dense forest, hence their shading of sediment is patchy at the edges and shaded patches are often comparatively small. We did our experiment on the edges of the mangrove forests, where the sizes of the naturally shaded patches and our experimental plots more closely match. However, the size we chose for our plots was a trade-off between area shaded and having a manageable roof size. In addition, our shading manipulation was a persistent change in shading, similar to that caused by structures such as bridges; whereas shading due to immersion and emersion is periodic and hence so are the impacts (Drylie et al., 2018). Thus, the extrapolation of our findings to larger scale and different types of shading should be treated with appropriate caution.

Originally, the clear roofs were incorporated into the experiment as a procedural control to unconfound contrasts between the unshaded control plots and the heavily shaded plots, which potentially differed not only with respect to shading, but in other factors that may be altered by the presence of the roofs, e.g., changes to water-movement, reduced predation, mobile fauna sheltering under roofs during high and/or low tide, etc. (Miller and Gaylord, 2007). For amphipod abundance there appeared to be an experimental artifact of roofs, with a significant decrease 

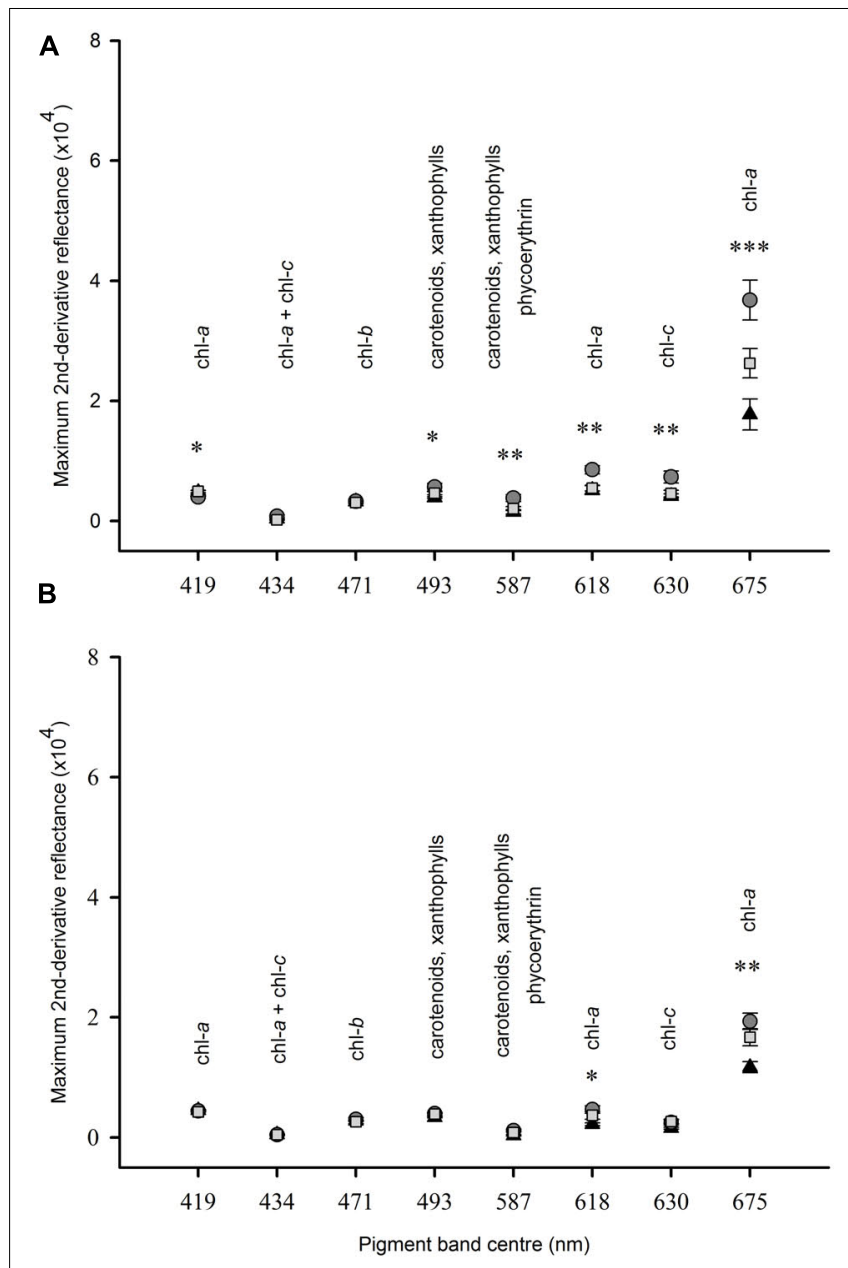

C

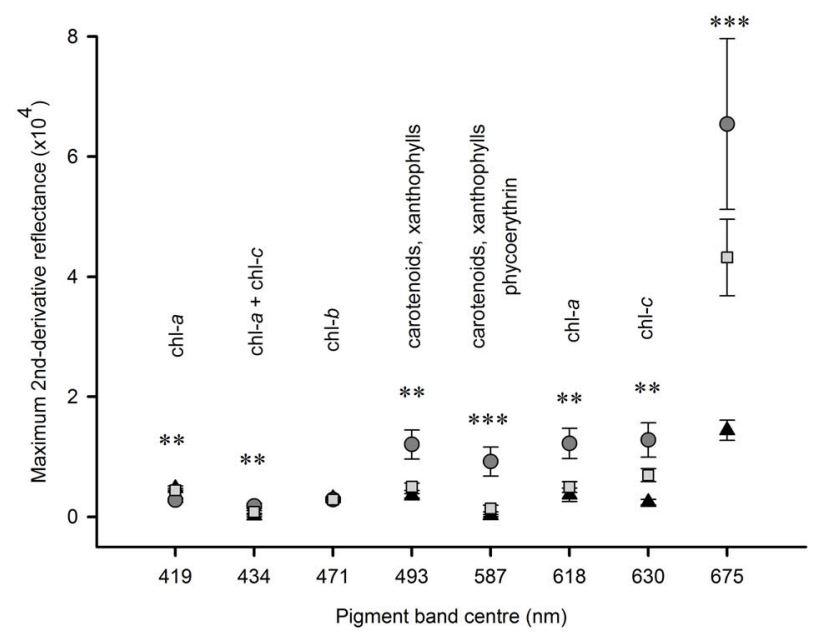

FIGURE 5 | Mean (SE) amount of absorption by pigments at different wavelengths between 400 and $800 \mathrm{~nm}$ under heavy shading ( $\mathbf{\Lambda}$ ); light shading (•); unshaded control plots ( $\square$ ). Panel (A) after 2 weeks at Tambourine Bay, $n=2$; (B) after 2 weeks at Gore Creek, $n=4$; (C) after 3 months at Tambourine Bay, $n=4$. Data were analyzed using ANOVA on untransformed data, asterisks indicate significance, ${ }^{*} p<0.05,{ }^{* *} p<0.01,{ }^{* * *} p<0.001$. in abundances of amphipods after 3 months under both sets of roofs compared to the unshaded control plots. For most of the significant responses shown by the taxa and the sedimentary properties to shading, measures under the clear and black roofs showed opposite directional responses, so are very unlikely to be due to an artifact associated with the structure itself.

\section{Effects of Addition of Nutrients}

The only significant effect was a small decrease in biochemically measured chlorophyll $a$ and colloidal carbohydrate in the plots with added nutrients. This was opposite to what would be predicted if algal growth was nutrient limited. Despite biotic processing of mangrove leaves increasing nutrients in sediment (Camilleri, 1992) and nutrient addition altering faunal assemblages (Morris and Keough, 2003); adding a source of nutrients to sediments does not always result in either measurable increases in nutrients (Douglas et al., 2016), nor changes to fauna (Rossi, 2006), nor an overall increase in primary productivity or biomass of microphytobenthos (Stutes et al., 2006; Cebrián et al., 2012), but can alter assemblage structure (Gladstone-Gallagher et al., 2014b), for example by inducing cyanobacterial blooms (Armitage and Fong, 2004).

The effect of nutrient addition can also be mediated by other organisms, for example the crab Pachygrapsus crassipes, via processes such as bioturbation, reduced the relative importance of nutrients to soft-sediment benthic assemblages (Armitage and Fong, 2006). It is possible that the crab species found in our sites, such as the burrowing Heloecius cordiformis, have a similar effect on nutrients. Nutrient additions to intertidal flats have been shown to increase chlorophyll $a$ concentration in the sediment by $90 \%$, but only where resource uptake efficiency and the accumulation of algae in plots were facilitated by the addition of high densities of a burrowing bivalve (Eriksson et al., 2017).

These results suggest that microphytobenthos in this part of Sydney Harbour are not nutrient limited, although it has been shown that fertilizer application rate and sediment properties influence enrichment level (Douglas et al., 2016) and it is possible that we did not get sufficient nutrient release to detect an effect. The results also suggest that the differences in patterns of microphytobenthos, carbohydrates and fauna found between unshaded sediment without large amounts of surface litter and the shaded sediment with surface litter (Chapman and Tolhurst, 2004, 2007; Tolhurst and Chapman, 2007), represents a much more complex interaction of many different factors (see below sections and Kon et al., 2010) than a simple increase in nutrients derived from leaf litter. A unified approach to field-based sediment nutrient enrichment experiments is required to enhance comparisons and future meta-analyses (Douglas et al., 2016).

\section{Effects of Shading on the MPB and Properties of the Sediment}

Changes in the properties of sediments due to shading were primarily in the measures of microphytobenthos and properties known to be altered by them. This is most likely due to the 
altered light availability, although changes to temperature and moisture may have also contributed. Visual observations and the changes in sediment properties indicate that there was generally an increase in microphytobenthos biomass in the lightly shaded plots and a decrease in the more heavily shaded plots. Fewer variables were significantly altered at Gore Creek, demonstrating spatial variability in the response to shading. Originally, chlorophyll $a$ and colloidal carbohydrate were predicted to increase under black roofs (heavy shading), because of the patterns previously documented between unshaded mud and mud shaded by the mangrove canopy (Chapman and Tolhurst, 2004; Tolhurst and Chapman, 2007), which the black roofs were expected to mimic. However, the black roofs caused more shading than the mangrove canopy and there was either no significant response in chlorophyll $a$ and colloidal carbohydrate or the opposite response occurred. Altered light intensity directly causes shifts in the microphytobenthos, e.g., in: pigment ratios, amount of chlorophyll proteins, species composition, growth, survival, migration of motile species, number and/or size of light harvesting subunits (Gallagher et al., 1984; Hust et al., 1999; Defew et al., 2004; Jesus et al., 2006; Stutes et al., 2006; van Leeuwe et al., 2008; Perkins et al., 2010; Cartaxana et al., 2016); although the contribution of an indirect effect of shading via macrofauna cannot be ruled out. In the unshaded control plots, high light levels are most probably driving motile microphytobenthos cell migration downward in the sediment profile or inducing photoinhibition, at least during parts of the day. Under heavy shading, light availability is probably limiting microphytobenthic photosynthesis.

On rocky shores and seawalls, shading ameliorates stressful conditions (Blockley, 2007), for example by decreasing physical stresses associated with emersion during low tide, particularly temperature and desiccation (Thompson et al., 2004). Mangrove canopy directly alters physical conditions such as temperature and moisture, with concomitant changes to sediment properties and organisms (Kon et al., 2011). Latitude and its effects on temperature, insolation and day-length play an important role in regulating microphytobenthos biomass and their response to shading. Murphy et al. (2009) suggested that increased insolation and temperatures were responsible for a decrease in microphytobenthos biomass during warmer months in these intertidal flats. The results from Tambourine Bay after 3 months are in line with that suggestion, with the light shading at least partially emulating conditions found in cooler months (i.e., increased sediment moisture and decreased light intensity). The increased concentration of water in the sediment under light shading is probably due to shading decreasing temperatures and evaporation during emersion (Kon et al., 2010), and/or the increase in microphytobenthos biomass, and decrease in sand increasing water retention (the method for measuring water does not differentiate between pore water and water found within organisms). The increase in colloidal carbohydrate at Tambourine Bay after 3 months is probably primarily due to the increase in microphytobenthos, which are known to correlate with amounts of carbohydrate (Underwood, 1997b; Tolhurst et al., 2008). Over the whole study, however, the differences in pigments and photosynthetic measures are mixed, suggesting that either the microphytobenthic community is mixed, exhibiting unique responses, or that something else in addition to the microphytobenthos is impacting the carbohydrates.

After 3 months, heavily shaded plots showed directional responses in sediment properties in line with a reduction in microphytobenthos (except for grain size), including reductions in $F_{\mathrm{o}}$, chlorophyll $a$, colloidal carbohydrate, erosion threshold and total carbohydrate; and increased erosion rate and water; although the differences were not always significant (Figure 8). The lightly shaded plots showed directional responses in line with an increase in microphytobenthos biomass; including increases in $F_{\mathrm{o}}$, chlorophyll $a$, chlorophyll $b$, colloidal carbohydrate, total carbohydrate, erosion threshold, mud (both types of core), and water; and decreased erosion rate and amounts of sand (both types of core), although the differences were not always significant (Figure 8).

The amounts and types of pigments in microphytobenthos can yield important information on the composition of the microphytobenthic assemblage (reviewed by Millie et al., 1993). Amounts of pigments can also change in response to variations in the intensity and wavelength distribution of incident light. Carotenoids, for example, play an important role in protecting algae from intense sunlight (Young and Britton, 1990) and changes in amounts of their oxidized derivatives, xanthophylls, are known to occur over relative short time-intervals in some micro-algae (e.g., Demers et al., 1991).

After 2 weeks in Tambourine bay (experiment 1), shading had a significant effect on the amounts of pigments (as measured by the strength of their absorption spectra), with carotenoids, xanthophylls, chlorophyll $a(419,618$, and $675 \mathrm{~nm})$ and chlorophyll $c(630 \mathrm{~nm})$ greater in lightly shaded plots than where plots were either heavily shaded or unshaded. The absorption due to chlorophyll $a$ at $675 \mathrm{~nm}$ was greatest in lightly shaded plots and smallest in heavily shaded plots, indicating that microphytobenthos biomass was increased in lightly shaded plots and decreased under more heavy shading. This agrees with the $F_{\mathrm{o}}$ and biochemically measured chlorophyll $a$ data. These data do not indicate that pigments were responding differently between treatments at this time.

After 2 weeks in Gore Creek (experiment 2), there was little effect of shading on absorptions, with a small significant decrease in chlorophyll $a$ (618 and $675 \mathrm{~nm}$ ) under heavy shading, indicating a small decrease in microphytobenthos biomass. Again, there was no indication that pigments were responding differently between treatments.

After 3 months at Tambourine Bay (experiment 2) absorption by chlorophylls $a, b$ and $c(419,424$, and $471 \mathrm{~nm})$ was so strong that the spectrum became flat and individual bands could not be easily resolved. This may explain why differences in absorption among treatments were smaller in this spectral region compared with other absorptions at longer wavelengths caused by the same pigments (compare chlorophyll $a$ derivative reflectance at $419 \mathrm{~nm}$ with that at $675 \mathrm{~nm}$ in Figure 5C). The different amount and direction of responses in absorption at different wavelengths under different shading treatments suggests that as well as changes in microphytobenthos biomass, there may be some 


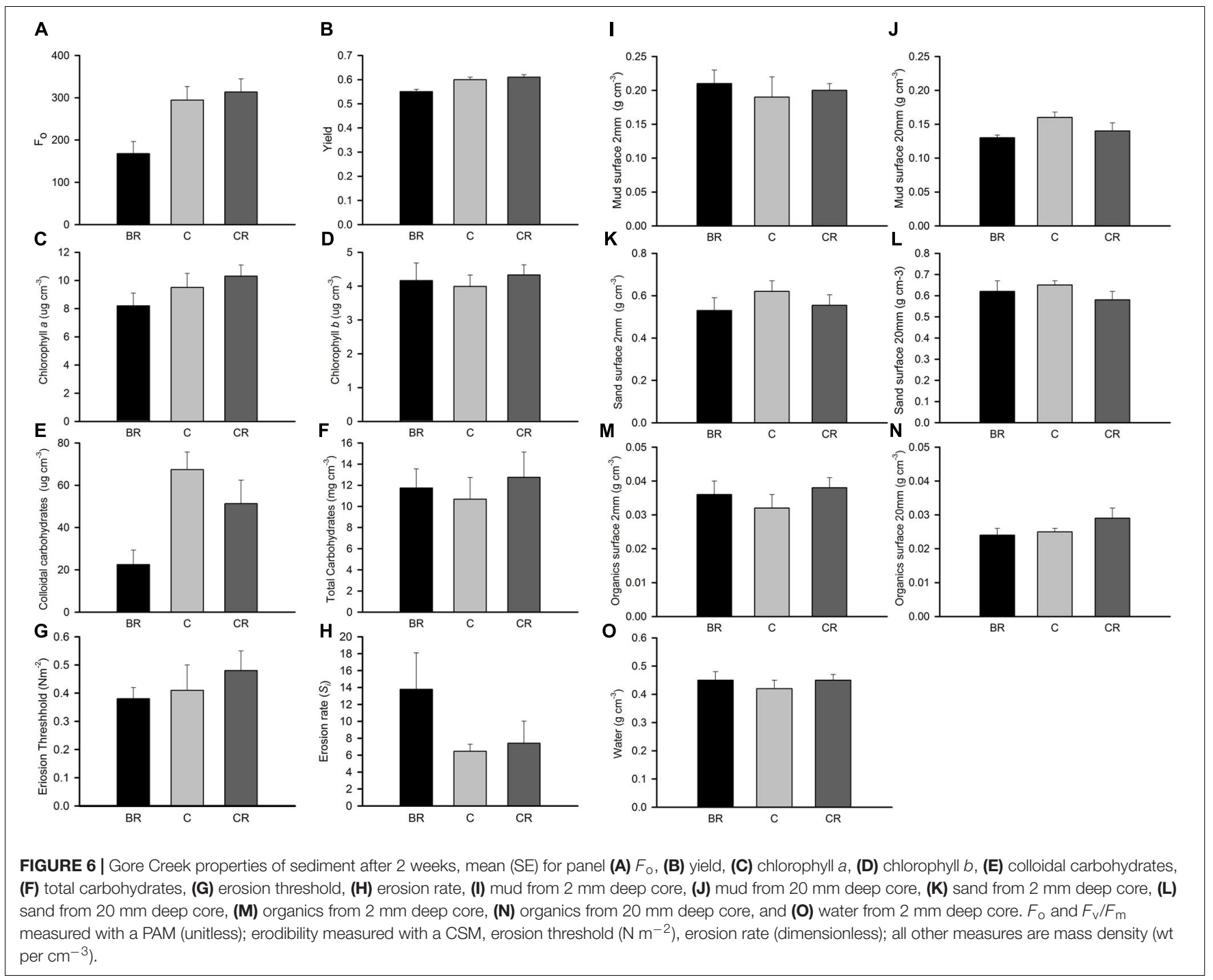

TABLE 2 | Analyses of major components of fauna and selected properties of sediments in plots (P) subjected to Shading (Sh), with appropriate control treatment; experiment 2 at Tambourine Bay after 3 months; details in text.

(A)

\begin{tabular}{lccccccccc}
\hline Source & df & No. taxa & Fams. Poly. & Oligochaetes & Capitellids & Spionids & Sabellids & Nereidids & Amphipods Nematodes Bivalves \\
\hline Sh & 2 & $*$ & - & - & - & - & - & - & $*$ \\
$\mathrm{P}(\mathrm{Sh})$ & 15 & - & $*$ & - & $*$ & - & - & $*$ & $*$ \\
\hline
\end{tabular}

(B)

\begin{tabular}{lccccccccc}
\hline Source & df & $\boldsymbol{F}_{\mathbf{0}}$ & $\boldsymbol{F}_{\mathbf{v}} / \boldsymbol{F}_{\mathbf{m}}$ & Chl. $\boldsymbol{a}$ & Chl. $\boldsymbol{b}$ & Coll. Carb & Total Carb. & Eros. thres. & Eros. rate \\
\hline $\mathrm{Sh}$ & 2 & $\star \star$ & $*$ & $* \star$ & - & $* \star$ & $* *$ & - & - \\
$\mathrm{P}(\mathrm{Sh})$ & 15 & $* \star \star$ & $*$ & $* \star \star$ & $* \star$ & $* \star$ & - & - & -
\end{tabular}

(C)

Source df Mud $(20 \mathrm{~mm})$ Mud $(2 \mathrm{~mm})$ Sand $(20 \mathrm{~mm})$ Sand $(2 \mathrm{~mm})$ Organics $(20 \mathrm{~mm})$ Organics $(2 \mathrm{~mm})$ Water $(2 \mathrm{~mm})$

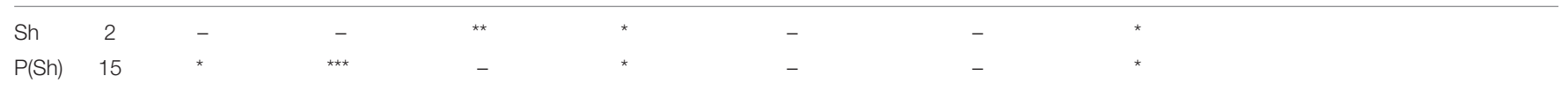

2 samples from each of $n=6$ replicate plots. Asterisks indicate significance, ${ }^{*} p<0.05,{ }^{* *} p<0.01,{ }^{* * *} p<0.001$. 


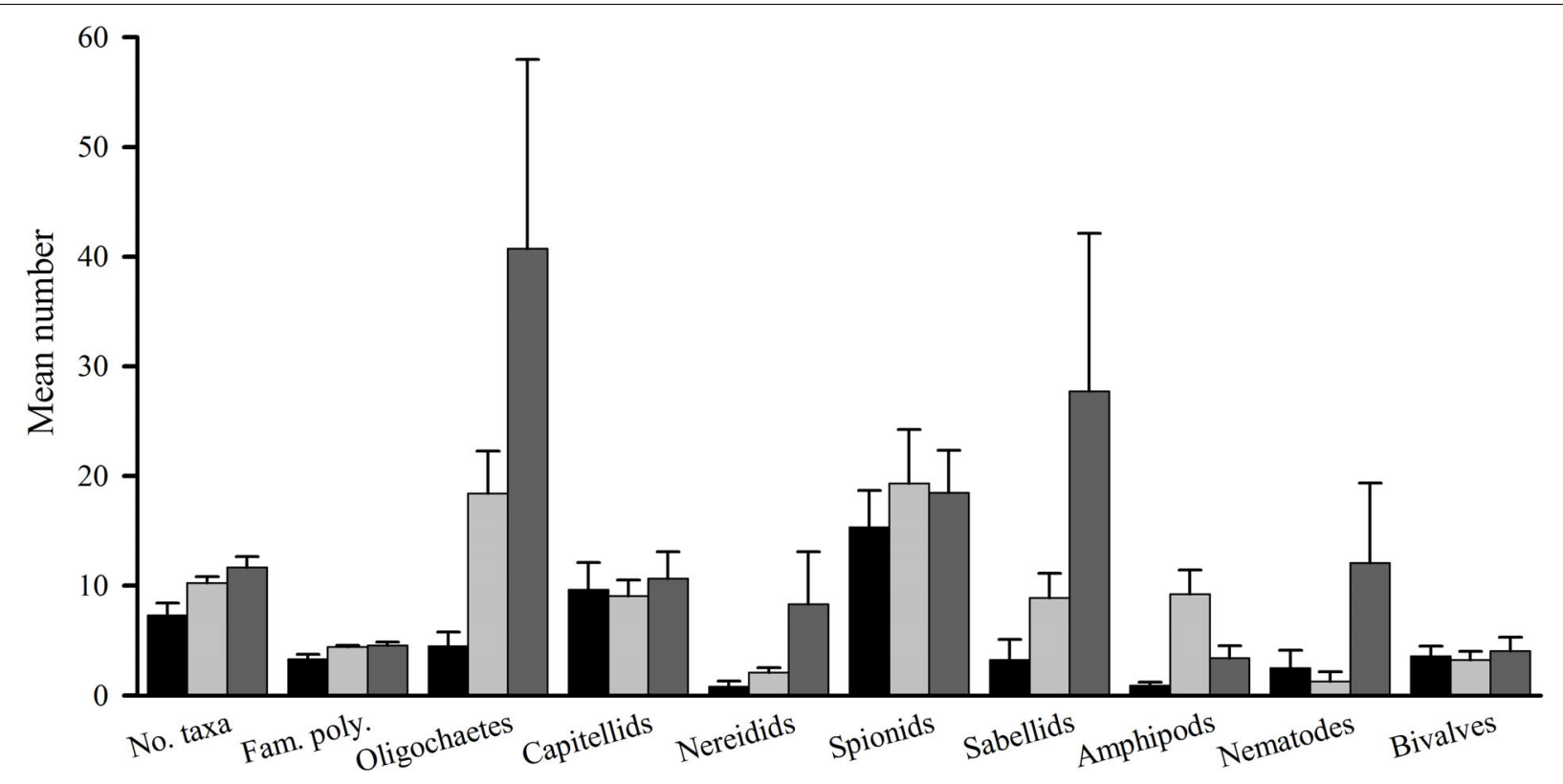

FIGURE 7 | Tambourine Bay macrofauna after 3 months. Mean (SE; $n=6$ plots) number of taxa, families of polychaetes and abundance of oligochaetes, capitellids, nereidids, spionids, sabellids, amphipods, nematodes, and bivalves in heavily shaded plots with black roofs (black bars), lightly shaded plots with clear roofs (dark gray bars), and unshaded control plots (light gray bars).

physiological shifts in pigment composition and/or behavioral responses such as migration by diatoms and/or a change in the species composition of the microphytobenthos assemblage due to different amounts of shading. Directional changes in absorption due to chlorophyll $c(630 \mathrm{~nm})$ suggest that there might have been greater numbers of diatoms under lightly shaded conditions and fewer under heavily shaded conditions. This would support the interpretation that the increase in colloidal carbohydrates under light shading was due to microphytobenthos, because diatoms are known to secrete copious amounts of carbohydrates (Underwood and Smith, 1998; Paterson et al., 2000; Tolhurst et al., 2008) and removal of microphytobenthos with algaecide in these habitats causes significant reduction in colloidal carbohydrate (Murphy and Tolhurst, 2009).

When light levels are large, excess photosynthetic production, particularly in diatoms, is used to produce extracellular carbohydrates that can be utilized later, for example at night (Lancelot and Mathot, 1985; de Brouwer and Stal, 2002). The patterns in colloidal carbohydrate (heavy shading $<$ unshaded controls < light shading) suggest that in heavily shaded plots there is a reduction in carbohydrate production and the utilization of available carbohydrates; when there is no shading there is less carbohydrate production compared to lightly shaded plots (possibly due to photoinhibition and/or high temperatures); whilst under light shading there is excess carbohydrate production. Measurements of the seasonal changes in microphytobenthos on these intertidal flats using spectroradiometry and PAM fluorescence demonstrated that microphytobenthos biomass increased in cooler months and decreased in warmer months (Murphy et al., 2009), suggesting that the effects of shading on microphytobenthos may be partially due to changes in temperature and moisture as well as altered light intensity.

It is possible that the fauna also affects the carbohydrates, most likely through total carbohydrates. For example, there were increased numbers of worms in unshaded sediment, which are known to secrete carbohydrates during construction of burrows (Meadows et al., 1990). However, whilst carbohydrates may be increased locally on burrow surfaces, the net effects of worms and other fauna tends to be a reduction in colloidal carbohydrates (Hu et al., 1995; de Deckere et al., 2001). Further work is required to elucidate causative relationships between the fauna and properties of the sediments, such as carbohydrates and how these relate to carbohydrate production from other sources, such as bacteria.

Both types of roof (levels of shading) tended to decrease the concentration of sand in the surface $\sim 2 \mathrm{~mm}$ of sediment, with a particularly large decrease after 3 months in lightly shaded sediment, accompanied by a concomitant increase in water (Figure 8). The concentration of mud, however, showed relatively small changes. The reduction in sand concentration and increase in water concentration means there was a shift to finer grained, less consolidated surface sediment under both types of roof after 3 months. This may represent a direct artifact of the roofs, e.g., by altering local hydrodynamics (there was evidence of this at Gore Creek after the storm) or an indirect effect, via changes in the microphytobenthos and fauna. Diatom biofilms are better at stabilizing finer sediment than coarser sediment (Fagherazzi et al., 2013), suggesting microphytobenthos preferentially trap fine sediment. The decreased amount of sand is thus consistent with both an artifact of the roofs on hydrodynamics, and an increased biomass of microphytobenthos. 


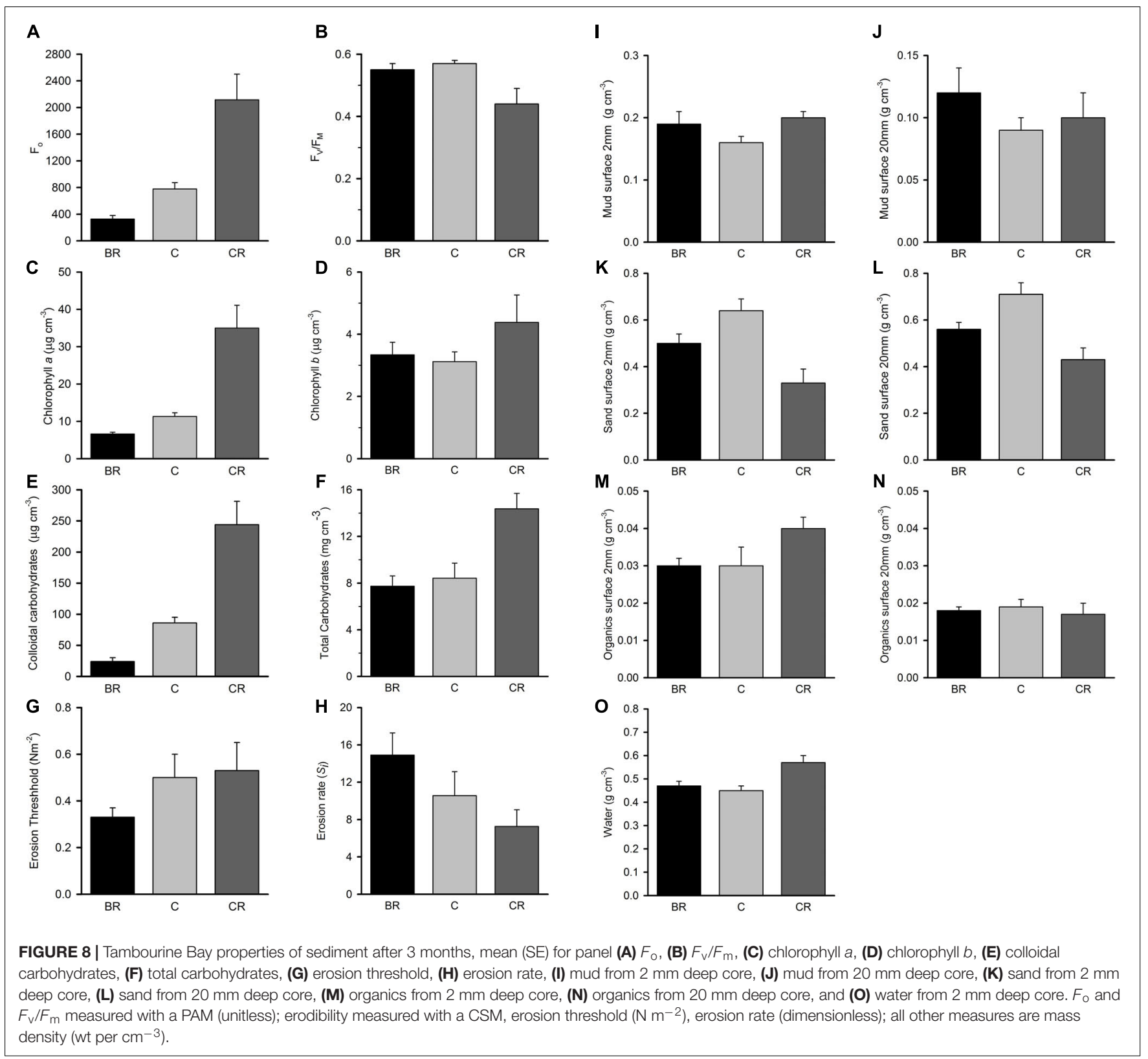

Despite considerable increases in microphytobenthos under light shading and decreases under heavy shading, there were only relatively minor changes in erosion threshold and relative erosion rate $\left(S_{i}\right)$. This was surprising because microphytobenthos are known to stabilize sediments (Tolhurst et al., 2006a,b; Tolhurst et al., 2008). Similar limited effects on erodibility in response to shading have been found in work on the sandflats in Manukau Harbour (Harris et al., 2015). Directional responses were, however, generally consistent with the changes in microphytobenthos biomass and biostabilization, particularly for the relative erosion rate $\left(S_{i}\right.$ heavy shading $>$ unshaded controls > light shading). The limited effect of shading on erodibility can be explained by consideration of the other sediment properties, changes in macrofauna and the nature of biostabilization. The large changes in amounts of sand, water and to a lesser extent mud suggest that there was a shift to finer grained, unconsolidated sediment under each type of roof, which would be less stable than the unshaded control sediment. These changes in the physical composition of the sediment would act in an antagonistic fashion to the stabilizing effect of the microphytobenthos. Oligochaetes were more abundant in lightly shaded sediment and less abundant in heavily shaded sediment and have been shown to significantly reduce algal biomass at the sediment surface (van Regteren et al., 2017), probably with cascading effects causing a reduction in sediment stability and increase in erodibility. Thus, an increase in oligochaetes would also act in an antagonistic fashion to the stabilizing effect of the microphytobenthos and could explain why the 
effect of shading on microphytobenthos and related sediment properties were not as large as otherwise might be expected. Thus, the net effect of changes in physical properties, macrofauna and microphytobenthos are to increase sediment erodibility in heavily shaded conditions and generally decrease erodibility in lightly shaded conditions, although effects were generally small. Antagonistic effects and variability in the relative magnitude of the physical and biological contributions to erodibility would explain why the lightly shaded sediment is not always more stable than the unshaded sediment, despite the general increase in microphytobenthos in lightly shaded conditions. Finally, microphytobenthos do not always stabilize sediment (e.g., Sutherland et al., 1998; Tolhurst et al., 2008).

\section{Effects of Shading on the Fauna}

Despite clear effects of shading on the sediment, it had less effect on the fauna. Shading was predicted to increase abundances of amphipods and insect larvae and decrease abundances of oligochaetes and polychaetes in accordance with patterns of abundance found between unshaded mud and shaded mud under the canopy of the trees (Chapman and Tolhurst, 2004; Tolhurst and Chapman, 2007). In a mangrove forest in Thailand, manipulative experiments by Kon et al. (2010) showed species richness and abundance of epifauna increased in shaded treatments due to lower temperature and higher moisture.

After 2 weeks, there was no effect of shading on the entire assemblage in either location. There were, however, changes to individual taxa, some of which were as predicted. Heavy shading in experiment 1 at Tambourine Bay did not decrease abundance of all polychaetes, only reducing abundance of spionids and capitellids (Figure 2), which made up the majority of the worms. Oligochaetes were decreased in both shading treatments when nutrients were added and increased in both shading treatments when nutrients were not added, but increased in lightly shaded plots and unshaded plots in the procedural control for nutrient addition. This is difficult to explain. After 2 weeks in experiment 2 at Gore Creek, abundance of oligochaetes also decreased slightly in deeply shaded plots, as predicted, but increased under light shading (Figure 3). Spionids and capitellids are opportunistic taxa, with abundances that change rapidly in response to changes in resources (Levin, 1984). Because many small polychaetes are capable of dispersal through the water-column, the decrease in abundance may have been due to emigration or mortality. Spionids primarily live in temporary tubes, feeding across the surface of the mud around the tubes, whereas capitellids are shallow deposit-feeders. The decreases in capitellids and spionids under shade are likely to be a direct response to reduction of food; either the amount of microphytobenthos, or perhaps bacteria, or meiofauna.

After 3 months, there were significant changes in the faunal assemblage in deeply shaded plots compared to the other treatments. This was primarily due to large decreases in oligochaetes and sabellid polychaetes, but there was little change in the numbers of capitellids or spionids. In lightly shaded plots, abundance of oligochaetes, nereids, sabellids, and nematodes increased, which is opposite to what was predicted (Chapman and Tolhurst, 2004; Tolhurst and Chapman, 2007), although differences were not statistically significant due to the large variability in the data (Figure 7). Insect larvae and amphipods, predicted to increase in the shade, showed no significant change, suggesting that shading alone does not determine their natural patterns of abundance in mangroves. They are probably more influenced by other factors such as physical structure of mangrove plants or the distribution/amounts of leaf litter detritus (Chen and Ye, 2011), which can offer shelter and food.

\section{Future Research}

There is a wide variety of different types of natural and anthropogenic shading on intertidal flats, including persistent (e.g., docks, jetties, and mangrove canopy) and transient (moored boats, turbidity, and planktonic algal blooms), which vary spatially and temporally. This study shows that both light and heavy shading can significantly alter properties and processes at the sediment-water interface over a relatively short time period. Future studies should investigate how the different types, frequencies and duration of shade stress alter properties and processes on intertidal flats to identify specific thresholds or optimum conditions, with the ultimate goal of minimizing negative anthropogenic impacts to these environments.

\section{CONCLUSION}

Shading had major effects on microphytobenthos and related sediment properties, but patterns were not always as predicted and there was less of an effect on the macrofauna. Changes in the amount and intensity of shading of intertidal sediments, e.g., from anthropogenic (wharves, jetties etc.) or natural sources (mangrove forests) will alter various components of intertidal flat sediments, particularly microphytobenthos and associated properties. Changes in the microphytobenthos only caused small changes in sediment erodibility. Further research on the effects of shading on microphytobenthos, including detailed taxonomic analysis are required to determine the contributions of changes in biomass, species composition, photoinhibition, physiology, pigment composition and migration to the patterns found here. As shown in the current study, changes to the macrofauna are complex and variable, so before any environmental effects of increased shading on fauna can be understood, it is necessary to separate direct effects of shading on fauna from indirect effects, such as the changes to microphytobenthos or other resources. This requires appropriate experimental designs that can separate and measure the relative strengths of direct and indirect interactions between the biota and the sediment and the influence of external environmental conditions on these interactions. This is a major challenge for intertidal flat research.

\section{DATA AVAILABILITY STATEMENT}

The raw data supporting the conclusions of this article will be made available by the authors, without undue reservation, to any qualified researcher. 


\section{AUTHOR CONTRIBUTIONS}

MC, TT, and RM conceptualized the study and designed the experiments. TT and RM participated in the field setup and sampling. MC analyzed the macrofauna data. TT analyzed the CSM, PAM, and biogeochemical data. RM analyzed the spectroradiometry data. TT, MC, and RM wrote the manuscript.

\section{FUNDING}

This study was funded by the Australian Research Council through their Special Research Centre programme, an ARC

\section{REFERENCES}

Able, K. W., Manderson, J. P., and Studholme, A. L. (1998). The distribution of shallow water juvenile fishes in an urban estuary: the effects of manmade structures in the lower Hudson river. Estuaries 21, 731-744.

Aguirre-Gomez, R., Weeks, A. R., and Boxall, S. R. (2001). The identification cation of phytoplankton pigments from absorption spectra. Int. J. Remote Sens. 22, 315-338. doi: 10.1080/014311601449952

Anderson, M. J. (2001). A new method for non-parametric multivariate analysis of variance. Aust. Ecol. 26, 32-46. doi: 10.1111/j.1442-9993.2001.01070.pp.x

Armitage, A. R., and Fong, P. (2004). Upward cascading effects of nutrients: shifts in a benthic microalgal community and a negative herbivore response. Oecologia 139, 560-567. doi: 10.1007/s00442-004-1530-6

Armitage, A. R., and Fong, P. (2006). Predation and physical disturbance by crabs reduce the relative impacts of nutrients in a tidal mudflat. Mar. Ecol. Prog. Ser. 313, 205-213. doi: 10.3354/meps313205

Bidigare, R. R., Morrow, J. H., and Kiefer, D. A. (1989). Derivative analysis of spectral absorption by photosynthetic pigments in the Western Sargasso Sea. J. Mar. Res. 47, 323-341. doi: 10.1357/002224089785076325

Birch, G. F., Cruickshank, B., and Davis, B. (2010). Modelling nutrient loads to Sydney estuary (Australia). Environ. Monit. Assess. 167, 333-348. doi: 10.1007/ s10661-009-1053-z

Bishop, M. J., Mayer-Pinto, M., Airoldi, L., Firth, L. B., Morris, R. L., Loke, L. H. L., et al. (2017). Effects of ocean sprawl on ecological connectivity: impacts and solutions. J. Exp. Mar. Biol. Ecol. 492, 7-30. doi: 10.1016/j.jembe.2017.01.021

Black, K. S., Tolhurst, T. J., Paterson, D. M., and Hagerthey, S. E. (2002). Working with natural cohesive sediments. J. Hydraul. Eng. 128, 2-8. doi: 10.1061/(asce) 0733-9429(2002)128:1(2)

Blockley, D. J. (2007). Effect of wharves on intertidal assemblages on seawalls in Sydney Harbour, Australia. Mar. Environ. Res. 63, 409-427. doi: 10.1016/j. marenvres.2006.10.007

Byers, J. E., and Grabowski, J. H. (2014). “Soft-sediment communities," in Marine Community Ecology, eds M. D. Bertness, J. F. Bruno, B. R. Silliman, and J. J. Stachowicz, (Sunderland, MA: Sinauer), 227-249.

Camilleri, J. C. (1992). Leaf-litter processing by invertebrates in a mangrove forest in Queensland. Mar. Biol. 114, 139-145.

Cartaxana, P., Cruz, S., Gameiro, C., and Kühl, M. (2016). Regulation of intertidal microphytobenthos photosynthesis over a diel emersion period is strongly affected by diatom migration patterns. Front. Microbiol. 7:872. doi: 10.3389/ fmicb.2016.00872

Cebrián, J., Stutes, A. L., Phipps, S., Stutes, J. P., Christiaen, B., and Pennock, J. R. (2012). Effects of short-term sediment nutrient enrichment and grazer (Neritina reclivata) removal on sediment microalgae in a shallow eutrophic estuary (Alabama, USA). Rev. Biol. Trop. 60, 1687-1706.

Chapman, M. G. (1998). Relationships between spatial patterns of benthic assemblages in a mangrove forest using different levels of taxonomic resolution. Mar. Ecol. Prog. Ser. 162, 71-78. doi: 10.3354/meps162071

Chapman, M. G. (2003). Paucity of mobile species on constructed seawalls: effects of urbanization on biodiversity. Mar. Ecol. Prog. Ser. 264, 21-29. doi: 10.3354/ meps 264021
Discovery Grant (DP0559073), the Centre for Research on Ecological Impacts of Coastal Cities, and The University of Sydney. TT received additional support during writing from the University of East Anglia.

\section{ACKNOWLEDGMENTS}

Many research support staff in the Centre assisted in the field and laboratory, in particular C. Myers. The project has benefited from numerous discussions with A. J. Underwood and comments on the manuscript from A. Jackson.

Chapman, M. G., Blockley, D., People, J., and Clynick, B. (2008). "Effect of urban structures on diversity of marine species," in Ecology of Cities And Towns: A Comparative Approach, eds M. McDonnell, J. Breuste, and A. K. Hahs, (Cambridge: Cambridge University Press), 156-176. doi: 10.1017/ cbo9780511609763.010

Chapman, M. G., and Tolhurst, T. J. (2004). The relationship between invertebrate assemblages and bio-dependent properties of sediment in urbanized temperate mangrove forests. J. Exp. Mar. Biol. Ecol. 304, 51-73.

Chapman, M. G., and Tolhurst, T. J. (2007). Relationships between benthic macrofauna and biogeochemical properties of sediments at different spatial scales and among different habitats in mangrove forests. J. Exp. Mar. Biol. Ecol. 343, 96-109.

Chapman, M. G., Tolhurst, T. J., Murphy, R. J., and Underwood, A. J. (2010). Complex and inconsistent patterns of variation in benthos, micro-algae and sediment over multiple spatial scales. Mar. Ecol. Prog. Ser. 398, 33-47. doi: 10.3354/meps08328

Chapman, M. G., and Underwood, A. J. (2011). Evaluation of ecological engineering of "armoured" shorelines to improve their value as habitat. J. Exp. Mar. Biol. Ecol. 400, 302-311.

Chen, G. C., and Ye, Y. (2011). Restoration of Aegiceras corniculatum mangroves in Jiulongjiang Estuary changed macro-benthic faunal community. Ecol. Eng. 37, 224-228. doi: 10.1016/j.ecoleng.2010.10.003

Clarke, K. R. (1993). Non-parametric multivariate analyses of changes in community structure. Aust. J. Ecol. 18, 117-143. doi: 10.1111/j.1442-9993.1993. tb00438.x

Clynick, B. G., Chapman, M. G., and Underwood, A. J. (2008). Fish assemblages associated with urban structures and natural reefs in Sydney. Australia. Aust. Ecol. 33, 140-150. doi: 10.1111/j.1442-9993.2007.01802.x

de Brouwer, J. F. C., and Stal, L. J. (2002). Daily fluctuations of exopolymers in cultures of the benthic diatoms Cylindrotheca closterium and Nitzschia sp (Bacillariophyceae). J. Phycol. 38, 464-472. doi: 10.1046/j.1529-8817.2002. 01164.x

de Deckere, E., Tolhurst, T. J., and de Brouwer, J. F. C. (2001). Destabilization of cohesive intertidal sediments by infauna. Estuar. Coast. Shelf Sci. 53, 665-669. doi: 10.1006/ecss.2001.0811

Defew, E. C., Paterson, D. M., and Hagerthey, S. E. (2002). The use of natural microphytobenthic assemblages as laboratory model systems. Mar. Ecol. Prog. Ser. 237, 15-25. doi: 10.3354/meps237015

Defew, E., Perkins, R., and Paterson, D. (2004). The influence of light and temperature interactions on a natural estuarine microphytobenthic assemblage. Biofilms 1, 21-30. doi: 10.1017/s1479050503001054

Demers, S., Roy, S., Gagnon, R., and Vignault, C. (1991). Rapid light-inducedchanges in cell fluorescence and in Xanthophyll-cycle pigments of Alexandrium excavatum (Dinophyceae) and Thalassiosira pseudonana (Bacillariophyceae) - a photo-protection mechanism. Mar. Ecol. Prog. Ser. 76, 185-193. doi: 10.3354/ meps076185

Douglas, E. J., Pilditch, C. A., Hines, L. V., Kraan, C., and Thrush, S. F. (2016). In situ soft sediment nutrient enrichment: a unified approach to eutrophication field experiments. Mar. Poll. Bull. 111, 287-294. doi: 10.1016/j.marpolbul.2016. 06.096 
Drylie, T. P., Lohrer, A. M., Needham, H. R., Bulmer, R. H., and Pilditch, C. A. (2018). Benthic primary production in emerged intertidal habitats provides resilience to high water column turbidity. J. Sea Res. 142, 101-112. doi: 10. 1016/j.seares.2018.09.015

Dubois, M., Gilles, K. A., Hamilton, J. K., Rebers, P. A., and Smith, F. (1956). Colorimetric method for determination of sugars and related substances. Anal. Chem. 28, 350-356. doi: 10.1021/ac60111a017

Eriksson, B. K., Westra, J., van Gerwen, I., Weerman, E., van der Zee, E., van der Heide, T., et al. (2017). Facilitation by ecosystem engineers enhances nutrient effects in an intertidal system. Ecosphere 8:e02051. doi: 10.1002/ecs2.205

Fagherazzi, S., Fitzgerald, D. M., Fulweiler, R. W., Hughes, Z. J., Wiberg, P. L., McGlathery, K. J., et al. (2013). "12.13 ecogeomorphology of tidal flats," in Treatise on Geomorphology, ed. J. Shroder, (San Diego: Academic Press), 201220. doi: 10.1016/b978-0-12-374739-6.00403-6

Firth, L. B., Knights, A. M., Bridger, D., Evans, A. J., Mieszkowska, N., Moore, P. J., et al. (2016). Ocean sprawl: challenges and opportunities for biodiversity management in a changing world. Oceanogr. Mar. Biol. 54, 193-269.

Gallagher, J. C., Wood, A. M., and Alberte, R. S. (1984). Ecotypic differentiation in the marine diatom Skeletonema costatum - Influence of light-intensity on the photosynthetic apparatus. Mar. Biol. 82, 121-134. doi: 10.1007/bf00394096

Gladstone-Gallagher, R. V., Lundquist, C. J., and Pilditch, C. A. (2014a). Mangrove (Avicennia marina subsp. australasica) litter production and decomposition in a temperate estuary. New Zeal. J. Mar. Fresh. Res. 48, 24-37. doi: 10.1080/ 00288330.2013 .827124

Gladstone-Gallagher, R. V., Lundquist, C. J., and Pilditch, C. A. (2014b). Response of temperate intertidal benthic assemblages to mangrove detrital inputs. J. Exp. Mar. Biol. Ecol. 460, 80-88. doi: 10.1016/j.jembe.2014.06.006

Glasby, T. M., and Connell, S. D. (1999). Urban structures as marine habitats. Ambio 28, 595-598.

Grabowski, R. C., Droppo, I. G., and Wharton, G. (2011). Erodibility of cohesive sediment: the importance of sediment properties. Earth Sci. Rev. 105, 101-120. doi: 10.1016/j.earscirev.2011.01.008

Harris, R. J., Pilditch, C. A., Hewitt, J. E., Lohrer, A. M., Van Colen, C., Towsend, M., et al. (2015). Biotic interactions influence sediment erodibility on wave-exposed sandflats. Mar. Ecol. Prog. Ser. 523, 15-30. doi: 10.3354/meps11164

Hauxwell, J., Cebrian, J., and Valiela, I. (2003). Eelgrass Zostera marina loss in temperate estuaries: relationship to land-derived nitrogen loads and effect of light limitation imposed by algae. Mar. Ecol. Prog. Ser. 247, 59-73. doi: 10.3354/ meps 247059

Honeywill, C., Paterson, D. M., and Hagerthy, S. E. (2002). Determination of microphytobenthic biomass using pulse-amplitude modulated minimum fluorescence. Eur. J. Phycol. 37, 485-492. doi: 10.1017/s0967026202003888

Hu, S., Coleman, D. C., Hendrix, P. F., and Beare, M. H. (1995). Biotic manipulation effects on soil carbohydrates and microbial biomass in a cultivated soil. Soil Biol. Biochem. 27, 1127-1135. doi: 10.1016/0038-0717(95) 00041-c

Hust, M., Krumbein, W. E., and Rhiel, E. (1999). An immunochemical in situ approach to detect adaptation processes in the photosynthetic apparatus of diatoms of the Wadden Sea sediment surface layers. J. Microbiol. Methods 38, 69-80. doi: 10.1016/s0167-7012(99)00077-9

Jeffrey, S. W., Wright, S. W., and Zapata, M. (1999). Recent advances in HPLC pigment analysis of phytoplankton. Mar. Freshwat. Res. 50, 879-896.

Jesus, B., Perkins, R. G., Mendes, C. R., Brotas, V., and Paterson, D. M. (2006). Chlorophyll fluorescence as a proxy for microphytobenthic biomass: alternatives to the current methodology. Mar. Biol. 150, 17-28. doi: 10.1007/ s00227-006-0324-2

Kamruzzaman, M. D., Basak, K., Paul, S. K., Ahmed, S., and Osawa, A. (2019). Litterfall production, decomposition and nutrient accumulation in Sundarbans mangrove forests, Bangladesh. Forest Sci. Technol. 15, 24-32. doi: 10.1080/ 21580103.2018.1557566

Kon, K., Kurokura, H., and Tongnunui, P. (2010). Effects of the physical structure of mangrove vegetation on a benthic faunal community. J. Exp. Mar. Biol. Ecol. 383, 171-180. doi: 10.1016/j.jembe.2009.11.015

Kon, K., Kurokura, H., and Tongnunui, P. (2011). Influence of a microhabitat on the structuring of the benthic macrofaunal community in a mangrove forest. Hydrobiologia 671, 205-216. doi: 10.1007/s10750-011-0718-0

Lancelot, C., and Mathot, S. (1985). Biochemical fractionation of primary production by phytoplankton in Belgian coastal waters during short-term and long-term incubations with C-14C Bicarbonate. 1. Mixed diatom populations. Mar. Biol. 86, 219-226. doi: 10.1007/bf00397507

Lee, S. Y. (1999). Tropical mangrove ecology: physical and biotic factors influencing ecosystem structure and function. Aust. J. Ecol. 24, 355-366. doi: 10.1046/j.1442-9993.1999.00984.x

Lee, S. Y. (2008). Mangrove macrobenthos: assemblages, services, and linkages. J. Sea Res. 59, 16-29. doi: 10.1016/j.seares.2007.05.002

Levin, L. A. (1984). Life-history and dispersal patterns in a dense infaunal polychaete assemblage - Community structure and response to disturbance. Ecology 65, 1185-1200. doi: 10.2307/1938326

Lundkvist, M., Grue, M., Friend, P. L., and Flindt, M. R. (2007). The relative contributions of physical and microbiological factors to cohesive sediment stability. Cont. Shelf Res. 27, 1143-1152. doi: 10.1016/j.csr.2006.01.021

Markich, S. J., and Jeffree, R. A. (2019). Physico-chemical and key metal data for surface waters and sediments of the Sydney and Hawkesbury estuaries, Australia. Data Brief 252, 813-824. doi: 10.1016/j.dib.2019.104255

Meadows, P. S., Tait, J., and Hussain, S. A. (1990). Effects of estuarine infauna on sediment stability and particle sedimentation. Hydrobiologia 190, 263-266. doi: 10.1007/bf00008194

Miller, L. P., and Gaylord, B. (2007). Barriers to flow: the effects of experimental cage structures on water velocities in high-energy subtidal and intertidal environments. J. Exp. Mar. Biol. Ecol. 344, 215-228. doi: 10.1016/j.jembe.2007. 01.005

Millie, D. F., Paerl, H. W., and Hurley, J. P. (1993). Microalgal pigment assessments using high-performance liquid chromatography - a synopsis of organismal and ecological applications. Can. J. Fish. Aquat. Sci. 50, 2513-2527. doi: 10.1139/ f93-275

Morris, L., and Keough, M. J. (2003). Variation in the response of intertidal infaunal invertebrates to nutrient additions: field manipulations at two sites within Port Phillip Bay, Australia. Mar. Ecol. Prog. Ser. 250, 35-49. doi: 10.3354/ meps 250035

Morrisey, D. J., Swales, A., Dittmann, S., Morrison, M. A., Lovelock, C. E., and Beard, C. M. (2010). The ecology and management of temperate mangroves. Oceanogr. Mar. Biol. 48, 43-60.

Munsch, S. H., Cordell, J. R., Toft, J. D., and Morgan, E. E. (2014). Effects of seawalls and piers on fish assemblages and juvenile salmon feeding behavior. N. Am. J. Fish. Manag. 34, 814-827. doi: 10.1080/02755947.2014.91 0579

Murphy, R. J., and Tolhurst, T. J. (2009). Effects of experimental manipulation of algae and fauna on the properties of intertidal soft sediments. J. Exp. Mar. Biol. Ecol. 379, 77-84. doi: 10.1016/j.jembe.2009.08.005

Murphy, R. J., Tolhurst, T. J., Chapman, M. G., and Underwood, A. J. (2005a). Estimation of surface chlorophyll-a on an emersed mudflat using field spectrometry: accuracy of ratios and derivative-based approaches. Int. J. Remote Sens. 26, 1835-1859. doi: 10.1080/01431160512331326530

Murphy, R. J., Tolhurst, T. J., Chapman, M. G., and Underwood, A. J. (2005b). Remote-sensing of benthic chlorophyll: should ground-truth data be expressed in units of area or mass? J. Exp. Mar. Biol. Ecol. 316, 69-77. doi: 10.1016/j. jembe.2004.10.006

Murphy, R. J., Tolhurst, T. J., Chapman, M. G., and Underwood, A. J. (2009). Seasonal distribution of chlorophyll on mudflats in New South Wales, Australia measured by field spectrometry and PAM fluorometry. Estuar. Coast. Shelf Sci. 84, 108-118. doi: 10.1016/j.ecss.2009.06.003

Murphy, R. J., Underwood, A. J., Tolhurst, T. J., and Chapman, M. G. (2008). Fieldbased remote-sensing for experimental intertidal ecology: case studies using hyperspatial and hyperspectral data for New South Wales (Australia). Remote Sens. Environ. 112, 3353-3365. doi: 10.1016/j.rse.2007.09.016

Paterson, D. M., Tolhurst, T. J., Kelly, J. A., Honeywill, C., de Deckere, E. M. G. T., Huet, V., et al. (2000). Variations in sediment properties, Skeffling mudflat, Humber Estuary, UK. Cont. Shelf Res. 20, 1373-1396. doi: 10.1016/s02784343(00)00028-5

Perkins, R. G., Honeywill, C., Consalvey, M., Austin, H. A., Tolhurst, T. J., and Paterson, D. M. (2003). Changes in microphytobenthic chlorophyll $a$ and EPS resulting from sediment compaction due to dewatering: opposing patterns in concentration and content. Cont. Shelf Res. 23, 575-586. doi: 10.1016/s02784343(03)00006-2

Perkins, R. G., Lavaud, J., Serôdio, J., Mouget, J.-L., Cartaxana, P., Rosa, P., et al. (2010). Vertical cell movement is a primary response of intertidal benthic 
biofilms to increasing light dose. Mar. Ecol. Prog. Ser. 416, 93-103. doi: 10. 3354/meps08787

Porra, R. J., Thompson, W. A., and Kriedemann, P. E. (1989). Determination of accurate extinction coefficients and simultaneous-equations for assaying Chlorophyll $a$ and Chlorophyll $b$ extracted with 4 different solvents Verification of the concentration of Chlorophyll standards by atomicabsorption spectroscopy. Biochim. Biophys. Acta 975, 384-394. doi: 10.1016/ s0005-2728(89)80347-0

Pratt, D. R., Lohrer, A. M., Thrush, S. F., Hewitt, J. E., Townsend, M., Cartner, K., et al. (2015). Detecting subtle shifts in ecosystem functioning in a dynamic estuarine environment. PLoS One 10:e133914. doi: 10.1371/journal.pone. 0133914

Raffaelli, D. (1999). Nutrient enrichment and trophic organisation in an estuarine food web. Acta Oecol. 20, 339-461.

Rossi, F. (2006). Small-scale burial of macroalgal detritus in marine sediments: effects of Ulva spp. on the spatial distribution of macrofauna assemblages. J. Exp. Mar. Biol. Ecol. 332, 84-95. doi: 10.1016/j.jembe.2005.11.003

Saintilan, N., and Williams, R. J. (1999). Mangrove transgression into saltmarsh environments in south-east Australia. Glob. Ecol. Biogeog. 8, 117-124. doi: 10.1046/j.1365-2699.1999.00133.x

Sanger, D. M., Holland, A. F., and Gainey, C. (2004). Cumulative impacts of dock shading on Spartina alterniflora in South Carolina estuaries. Environ. Manage. 33, 741-748.

Saunders, R. J., and Connell, S. D. (2001). Interactive effects of shade and surface orientation on the recruitment of spirorbid polychaetes. Aust. Ecol. 26, 109-115. doi: 10.1111/j.1442-9993.2001.01090.pp.x

Savitzky, A., and Golay, M. J. E. (1964). Smoothing and differentiation of data by simplified least squares procedures. Analyt. Chem. 36, 1627-1639. doi: $10.1021 / \mathrm{ac} 60214 \mathrm{a} 047$

Smith, C. M., and Alberte, R. S. (1994). Characterization of in-vivo absorption features of Chlorophyte, Phaeophyte and Rhodophyte algal species. Mar. Biol. 118, 511-521. doi: 10.1007/bf00350308

Stutes, A. L., Cebrian, J., and Corcoran, A. A. (2006). Effects of nutrient enrichment and shading on sediment primary production and metabolism in eutrophic estuaries. Mar. Ecol. Prog. Ser. 312, 29-43. doi: 10.3354/meps312029

Sutherland, T. F., Grant, J., and Amos, C. L. (1998). The effect of carbohydrate production by the diatom Nitzschia curvilineata on the erodibility of sediment. Limnol. Oceanogr. 43, 65-72.

Takada, Y. (1999). Influence of shade and number of boulder layers on mobile organisms on a warm temperate boulder shore. Mar. Ecol. Prog. Ser. 189, 171-179.

Thompson, R. C., Norton, T. A., and Hawkins, S. J. (2004). Physical stress and biological control regulate the producer-consumer balance in intertidal biofilms. Ecology 85, 1372-1382.

Thrush, S. F., Hewitt, J. E., Parkes, S., Lohrer, A. M., Pilditch, C., Woodin, S. A., et al. (2014). Experimenting with ecosystem interaction networks in search of threshold potentials in real-world marine ecosystems. Ecology 95, 1451-1457.

Tolhurst, T. J., Black, K. S., and Paterson, D. M. (2009). Muddy sediment erosion: insights from field studies. J. Hydraul. Eng. 135, 73-87.

Tolhurst, T. J., Black, K. S., Shayler, S. A., Mather, S., Black, I., Baker, K., et al. (1999). Measuring the in situ erosion shear stress of intertidal sediments with the cohesive strength meter (CSM). Est. Coast. Shelf Sci. 49, 281-294.

Tolhurst, T. J., and Chapman, M. G. (2005). Spatial and temporal variation in the sediment properties of an intertidal mangrove forest: implications for sampling. J. Exp. Mar. Biol. Ecol. 317, 213-222.

Tolhurst, T. J., and Chapman, M. G. (2007). Patterns in biogeochemical properties of sediments and benthic animals among different habitats in mangrove forests. Aust. Ecol. 32, 775-788.

Tolhurst, T. J., Consalvey, M., and Paterson, D. M. (2008). Changes in cohesive sediment properties associated with the growth of a diatom biofilm. Hydrobiologia 596, 225-239.

Tolhurst, T. J., Defew, E. C., de Brouwer, J. F. C., Wolfstein, K., Stal, L. J., and Paterson, D. M. (2006a). Small-scale temporal and spatial variability in the erosion threshold and properties of cohesive intertidal sediments. Cont. Shelf Res. 26, 351-362.

Tolhurst, T. J., Defew, E. C., and Dye, A. (2010). Lack of correlation between surface macrofauna, meiofauna, erosion threshold and biogeochemical properties of sediments within an intertidal mudflat and mangrove forest. Hydrobiologia 652, 1-13.

Tolhurst, T. J., Defew, E. C., Perkins, R. G., Sharples, A., and Paterson, D. M. (2006b). The effects of tidally-driven temporal variation on measuring intertidal cohesive sediment erosion threshold. Aquat. Ecol. 40, 521-531.

Tolhurst, T. J., Underwood, A. J., Perkins, R. G., and Chapman, M. G. (2005). Content versus concentration: effects of units of measuring the biogeochemical properties of soft sediments. Est. Coast. Shelf Sci. 63, 665-673.

Underwood, A. J. (1997a). Experiments in Ecology: Their Logical Design and Interpretation Using Analysis of Variance. Cambridge: Cambridge University Press.

Underwood, A. J., Chapman, M. G., and Connell, S. D. (2000). Observations in ecology: you can't make progress on processes without understanding the patterns. J. Exp. Mar. Biol. Ecol. 250, 97-115.

Underwood, G. J. C. (1997b). Microalgal colonization in a saltmarsh restoration scheme. Estuar. Coast. Shelf Sci. 44, 471-481.

Underwood, G. J. C., and Smith, D. J. (1998). Predicting epipelic diatom exopolymer concentrations in intertidal sediments from sediment chlorophyll. Microb. Ecol. 35, 116-125.

Van Colen, C., Thrush, S. F., Parkes, S., Harris, R., Woodin, S. A., Wethey, D. S., et al. (2015). Bottom-up and top-down mechanisms indirectly mediate interactions between benthic biotic ecosystem components. J. Sea Res. 98, $42-48$.

van Leeuwe, M. A., Brotas, V., Consalvey, M., Forster, R. M., Gillespie, D., Jesus, B., et al. (2008). Photoacclimation in microphytobenthos and the role of xanthophyll pigments. Eur. J. Phycol. 43, 123-132.

van Regteren, M., Ten Boer, R., Meesters, E. H., and De Groot, A. V. (2017). Biogeomorphic impact of oligochaetes (Annelida) on sediment properties and Salicornia spp. seedling establishment. Ecosphere 8:e01872. doi: 10.1002/ecs2. 1872

Vardy, S., Saunders, J. E., Tolhurst, T. J., Davies, P. A., and Paterson, D. M. (2007). Calibration of the high-pressure cohesive strength meter (CSM). Cont. Shelf Res. 27, 1190-1199.

Whitcraft, C. R., and Levin, L. A. (2007). Regulation of benthic algal and animal communities by salt marsh plants: impact of shading. Ecology 88, 904-917.

Whitfield, A., and Elliot, M. (2011). "Ecosystem and biotic classifications of estuaries and coasts," in Treatise on Estuarine and Coastal Science, Vol. 1, eds E. Wolanski, and D. McLusky, (Amsterdam: Elsevier), 99-124.

Wiens, J. A. (1976). Population responses to patchy environments. Ann. Rev. Ecol. Syst. 7, 81-120.

Williams, G. A. (1994). The relationship between shade and molluscan grazing in structuring communities on a moderately-exposed tropical rocky shore. J. Exp. Mar. Biol. Ecol. 178, 79-95.

Young, A., and Britton, G. (1990). "Carotenoids and stress," in Stress Responses in Plants: Adaptation and Acclimation Mechanisms, eds R. G. Alscher, and J. R. Cumming, (New York, NY: Wiley-Liss), 87-112.

Conflict of Interest: The authors declare that the research was conducted in the absence of any commercial or financial relationships that could be construed as a potential conflict of interest.

Copyright (C) 2020 Tolhurst, Chapman and Murphy. This is an open-access article distributed under the terms of the Creative Commons Attribution License (CC BY). The use, distribution or reproduction in other forums is permitted, provided the original author(s) and the copyright owner(s) are credited and that the original publication in this journal is cited, in accordance with accepted academic practice. No use, distribution or reproduction is permitted which does not comply with these terms. 